\title{
Accounting for firm heterogeneity in global value chains
}

\author{
Fabienne Fortanier ${ }^{1}$, \\ Guannan $\mathrm{Miao}^{2}$, Ans Kolk ${ }^{3}$ \\ and Niccolò Pisani ${ }^{3}$
}

${ }^{1}$ De Nederlandsche Bank (DNB), Amsterdam, The Netherlands; ${ }^{2} \mathrm{OECD}$, Paris, France; ${ }^{3}$ Amsterdam Business School, University of Amsterdam,

Correspondence:

A Kolk, Amsterdam Business School, University of Amsterdam, Amsterdam, The Netherlands

e-mail: akolk@uva.nl Amsterdam, The Netherlands

\begin{abstract}
The growing interest in global value chains (GVCs) has been paired with a greater appreciation of the need for better measurement methods, as reflected by recent initiatives from academia and leading international organizations. This research note focuses on one method to measure GVCs that has been recommended in recent scholarly work, namely input-output models, but goes beyond the industry level of analysis by introducing intra-industry firm heterogeneity. Our illustrative application to multinational enterprises (MNEs) versus domestic firms' participation in GVCs enhances our understanding of their specific role in GVCs and how such engagement varies across countries and industries. While showing that MNEs' contribution to value-added exports is considerably smaller than what is suggested by traditional trade statistics, our findings also, interestingly, document that the higher import content of exports of MNEs can go hand in hand with the creation of local backward linkages as a function of their much higher specialization in only parts of the production process vis-à-vis domestic firms. By answering relevant questions on MNEs' engagement in GVCs that have hitherto been impossible to address comprehensibly and in a cross-country comparative setting, this application illustrates how the methodology has great potential for international business research.
\end{abstract}

Journal of International Business Studies (2020) 51, 432-453. https://doi.org/ | 0.1057/s4 |267-019-00282-0

Keywords: globalization; multinational enterprises (MNEs); input-output tables; trade in value-added; global value chains (GVCs)

The online version of this article is available Open Access

The majority of the work presented in this paper was conducted while the first author worked at the OECD Statistics and Data Directorate, Trade and Competitive Statistics Division. The paper reflects the author's personal views, not necessarily those of the OECD or DNB.

The paper also represents the second author's own view, not necessarily that of the OECD. Electronic supplementary material The online version of this article (https://doi.org/10.1057/s41267-019-00282-

0 ) contains supplementary material, which is available to authorized users.

Received: 26 July 2018

Revised: 29 September 2019

Accepted: 30 September 2019

Online publication date: 13 December 2019

\section{INTRODUCTION}

The rise and growth of global value chains (GVCs) has been one of the most dominant features of the international business (IB) landscape in recent decades. Fostered by significant technological change and the widespread adoption of policies aimed at reducing trade costs, coupled with investment liberalization, firms have increasingly fragmented their value chains across geographies. This phenomenon has naturally spurred widespread interest among the general public (e.g., The Economist, 2013) as well as extensive academic research. Scholars have investigated a variety of issues related to GVCs, including their geographical reach (Suder, Liesch, Inomata, Mihailova, \& Meng, 2015; Turkina, Van Assche, \& Kali, 
2016), the drivers influencing the decision of where to locate value activities and how to govern them (Bunyaratavej, Hahn, \& Doh, 2007, 2008; CuervoCazurra, Mudambi, \& Pedersen, 2018; Doh, Bunyaratavej, \& Hahn, 2009; Giroud \& Mirza, 2015), the effects of such "fine-slicing" on innovation processes (Andersson, Dasi, Mudambi, \& Pedersen, 2016; Mudambi, 2008), as well as on factor prices and wages in host economies (Grossman \& RossiHansberg, 2008; Hummels, Jørgensen, Munch, \& Xiang, 2014). ${ }^{1}$

Thus far, researchers have assessed GVCs and its implications mainly relying on enterprise surveys, international trade statistics, and input-output (IO) models. ${ }^{2}$ Research based on enterprise surveys has been preferred by IB scholars in view of the possibility to shed light on the role of firm heterogeneities, to the detriment, however, of producing macro-level and more broadly generalizable implications given the relatively limited size of the samples used. Research based on international trade statistics has been used to produce insights into the connections between countries considering the goods and services exchanged. However, trade statistics do not allow for the examination of inter-industry linkages that are crucial in GVCs. Research employing inter-country IO models, ${ }^{3}$ and that thus employs a combination of national supply-use (SU) or IO tables and international trade statistics, has given scholars the opportunity to offer an extensive macroeconomic assessment of both inter-country and inter-industry linkages. Studies relying on IO models therefore provide a more comprehensive description of GVCs compared to those using firm-level samples gathered via surveys as these are often very limited, including in their cross-country comparability. In addition, explicitly relating trade flows to the producing industries and their input structures, IO-based analyses also avoid the pitfalls of purely tradebased analyses. Yet, as explained further below, their hitherto exclusive reliance on industry-level data have prevented the assessment of the role of firm-level idiosyncrasies, thus not only obscuring important within-industry heterogeneity, but also introducing structural biases in GVC-related indicators.

The aim of this research note is to present a novel methodology developed at the OECD Statistics and Data Directorate that integrates the above-mentioned research tools. By using IO models that also account for firm heterogeneity, this new method can add much needed nuance to our understanding of how specific firm characteristics play a role in the formation and configuration of GVCs. This is very relevant for IB research because the novel methodology introduced here not only answers the call by Suder et al. (2015) to increase the use of IO models in our field but - by integrating country-, industry-, and firm-level analysis - also allows IB scholars studying GVCs to conduct comprehensive yet finegrained analyses.

To better illustrate the specificities of this new method and showcase its potential, we apply it to explicate how the engagement in GVCs of multinational enterprises (MNEs) differs from that of domestic firms (i.e., distinguishing between foreign-controlled affiliates and domestically controlled firms), ${ }^{4}$ in light of the extensive body of IB research investigating the influence of MNEs' presence in host countries. ${ }^{5}$ The results obtained in our application generate new insights into the extent to which MNEs rely - both directly and indirectly - on foreign versus local suppliers, and on how such engagement in GVCs varies across countries and industries. Specifically, while showing that MNEs' contribution to value-added exports is considerably smaller than what is suggested by traditional trade statistics, our findings also reveal that MNEs' higher import content of exports can go hand in hand with the creation of local backward linkages as a function of their much higher specialization in only parts of the production process. Although central to the IB field, these questions could not be addressed until now due to data limitations: both cross-country comparable firm-level microdata and international IO models are necessary to tackle them. This application thus illustrates the potential of the careful integration of these sources through the methodology presented here to shed new light on relevant features of MNEs and GVCs.

The remainder of this research note is organized as follows. The next section further explains the three different tools used to study GVCs that were introduced above. We subsequently describe the methodology developed at the OECD Statistics and Data Directorate to break down national IO tables into more granular groupings of firms and present the data sources used. This is followed by an illustrative application, focused on MNEs versus domestic firms' participation in GVCs, and a Discussion and Conclusion section that includes areas for further research. 


\section{RESEARCH TOOLS USED FOR MEASURING GVCS}

To date, three main research tools have been used to measure GVCs (for a more detailed assessment and discussion of each of them from an IB perspective see Suder et al., 2015). The first tool corresponds to enterprise surveys focused on specific firms and/or products. The resulting firm- and often product-level data is then utilized by scholars to generate highly valuable insights into specific aspects associated with the geographic disaggregation of value activities, for instance the rationale followed when selecting particular locations (e.g., Demirbag \& Glaister, 2010; Doh et al., 2009; Hahn, Bunyaratavej, \& Doh, 2011). However, by its very nature, this work is confined to the specificities of the firms included in the samples considered and therefore limited in its ability to generate implications at a broader, macroeconomic level, and typically not comparable or consistent with main macro-economic indicators.

The second research tool corresponds to international trade statistics, which can shed light on the global interrelations that exist between countries in terms of specific goods and services. For example, Fung, Yau, and Zhang (2011) focus on trade data from China and Hong Kong to show that the spurious flows of funds to and from China are strictly related to the preferential tax incentives conferred to foreign investors, and Dutt, Mihov, and Van Zandt (2013) use bilateral trade data to illustrate the effect of WTO/GATT membership on the product margins of trade. However, traditional trade statistics do not take into account that products exported by a given country are nowadays almost always made of parts and components that are at least partially, if not entirely, produced by third countries. This means that traditional trade statistics cannot provide insights into the final destination (of consumption) of exported products (and therefore on the ultimate dependency of a country or industry on foreign demand), or into the origin of imported products. The absence of a link to production also means that trade statistics cannot give insights into domestic and international inter-industry linkages, including on the growing role of services in the manufacturing process.

The third research tool used to analyze GVCs is inter-country IO models, which, by combining national SU or IO tables and international trade statistics, provide a comprehensive, macroeconomic statistical description of both inter-industry and inter-country linkages. This has recently become the preferred option to measure and analyze GVCs, ${ }^{6}$ especially amongst international economists. The adoption of this approach is in particular supported by large, newly developed datasets in academia (e.g., the World Input-Output Database, see Timmer, Dietzenbacher, Los, Stehrer, $\&$ de Vries, 2015) ${ }^{7}$ and by international organizations (e.g., the OECD-WTO Trade in Value Added initiative (TiVA), see OECD \& WTO, 2011), ${ }^{8}$ from which a plethora of new measures on GVCs can be derived (see, e.g., Ahmad, Bohn, Mulder, Vaillant, \& Zaclicever, 2017; Johnson \& Noguera, 2012; Koopman, Wang, \& Wei, 2014). Such indicators have supported new and insightful analyses of GVCs' features that have greatly contributed to the policy debate, highlighting for instance the importance of imports for export success, the need for well-developed domestic services industries that support manufacturing exports, and the changing relative importance of trading partners when looking at the ultimate sources and destinations of trade, rather than the immediate counterpart.

However, while analyses based on data derived from IO models have helped to significantly improve our understanding of inter-country and inter-industry economic interdependencies, they have until now been confined to viewing integration through the statistical prism of industries. This is despite the fact that it is well known that even within narrowly defined industries, firms show marked variations in terms of, for example, their productivity, capital, and skill intensity (Bernard, Jensen, Redding, \& Schott, 2007), as well as major differences in their levels of integration in GVCs and the benefits that accrue from that (including for employees). A focus on industries alone has also been shown to introduce structural biases in GVC-related estimates.

Among these three tools to study GVCs, IB scholars have typically privileged the use of survey data, also in view of the need to unveil the role of firm heterogeneities. This has, however, come at the cost of broader generalizability at the macro level, which is not really possible given limitations in survey samples. Moreover, firm-level survey data is by nature not sufficient to fully unveil the chain of backward and forward linkages because even questions about firms' linkages to suppliers or buyers cannot capture their entire supply chain 
which, as production is increasingly fragmented, is instead crucial to inform the nature and configuration of GVCs. At the same time, IO models largely used by international economists have furthered our understanding of important features of GVCs, but at the detriment of appreciating how firm-level idiosyncrasies play a role in such GVCs.

In what follows, we present and discuss a novel methodology to integrate these different research tools by constructing IO models that also account for firm heterogeneity and thus have the potential to generate new insights into how firm characteristics play a role in GVCs, while also avoiding structural biases in the analysis. One of the key features of the new methodology introduced here is to precisely allow for an assessment of firms' second- and third-order linkages (which can only be done using data from IO tables in conjunction with those on trade and production) while including the firm dimension through the identification of key determinants of firm heterogeneity.

This methodology builds on earlier work by Ahmad, Araújo, Lo Turco, and Maggioni (2011), who highlighted the potential scale of structural biases using Turkish national statistics and microdata. It was refined by Piacentini and Fortanier (2015) for the OECD and World Bank G20 report (2015), and subsequently mainstreamed in further applications, including in a collaboration between the OECD and Statistics Denmark (2017), and most recently in the OECD's SME and Entrepreneurship Outlook (OECD, 2019). As noted by Piacentini and Fortanier (2015, p. 3), their paper "provides a first attempt to open the black box of firm heterogeneity and trade in value added" and contains measures that should therefore "be considered as experimental and preliminary" (p. 4). Thus, their work should be contextualized as an initial exploration (of the methodology) using 2011 data.

The methodology presented in this research note contains several novelties vis-à-vis Piacentini and Fortanier's (2015) experimental attempt, in particular to ensure an improved alignment between the firm-level data with the macro-economic accounting frameworks (the System of National Accounts) into which they are integrated. These accounting frameworks form the foundation of the national accounts and balance of payments, and hence the official measures of GDP, production, consumption, and trade. While highly technical, these adjustments are not insignificant, and their introduction prevents important potential biases, as also recognized in Piacentini and Fortanier (2015) - see endnote 9 for further details on the novelties contained in the method presented here. ${ }^{9}$

Some publications have already started to introduce firm heterogeneity in the analysis of GVCs by breaking down national SU and IO tables, focusing on countries where heterogeneity is likely to have a significant impact on results, such as China and Mexico (see, e.g., De la Cruz, Koopman, Wang, \& Wei, 2010; Kee \& Tang, 2016; Koopman, Wang, \& Wei, 2012; Yang et al., 2013). While insightful contributions, they have all focused on an individual country, and thus do not help to shed further light on one of the foundational aspects of GVCs, i.e., their international nature. To tackle this issue, an OECD Expert Group has recently started working on a core statistical response through the development of what have become known as extended SU tables to be generated within national statistical production systems that could then be merged to allow for inter-country analyses (Ahmad \& Ribarsky, 2014). Although a number of countries such as the US (Fetzner \& Strassner, 2015), the Netherlands (Chong, Van Beveren, Verbiest, \& Van der Wal, 2016), Mexico (INEGI, 2017), and Costa Rica (Saborío, 2015) have made significant advances on this front, with plans to mainstream these activities in their regular statistical production systems, for many other countries it may still take some time before they will be able to generate such tables.

To help fill the gap before these extended SU tables will be mainstream across all countries, the OECD has been working to further develop this philosophy by producing breakdowns of national IO and SU tables on the basis of key firm characteristics for OECD countries (see Piacentini \& Fortanier, 2015; OECD \& World Bank, 2015). Along these lines, Lopez-González (2017) has recently used the same approach looking at several Asian countries. This also applies to the OECD Statistics Directorate and the Statistical Offices of the Nordic countries, which have further extended the number of firm characteristics considered in their analysis when examining the role of Nordic countries in GVCs (OECD \& Statistics Denmark, 2017). Building on this work, we elucidate the specifics of this novel methodology in the following section. To better explain its details, as mentioned in the Introduction, we subsequently present an illustrative application focusing on firm ownership - and specifically the distinction between MNEs and domestic firms - to examine GVCs in 19 OECD countries covering the years 2011-2014. 


\section{INTRODUCING FIRM HETEROGENEITY IN IO TABLES}

To be able to generate indicators on firm characteristics such as ownership, it is necessary to introduce firm characteristics into the core component that underpins the analysis of GVCs, i.e., a national IO (or SU) table. The basic structure of a national IO table with three industries is illustrated in Figure 7 in Section 1 of the Appendix. The core of the matrix describes the intermediate use relationships between industries, and is supplemented with columns for final demand (consumption, capital formation, exports etc.), and rows that (primarily) ${ }^{10}$ record industry value added and output. The dark colored cells specify the intermediate and final use of domestically produced products, while the lighter cells indicate intermediate and final use of imported products. Disaggregating a national IO table by firm characteristics requires breaking down the columns, and subsequently the rows, by firm type, using information derived from business and trade statistics. The resulting table (presented in Figure 8 in Section 1 of the Appendix) shows an enlarged matrix of intermediate and final use relationships that indicates not only how industries but also different types of firms within an industry are interconnected. Five core steps are involved in this transformation, which are described in detail in Section 1 of the Appendix, involving the transparent and sequential breakdown of the columns (first value added and output, subsequently import use, then domestic intermediate use) and the rows (exports, followed by intermediate and final demand) that avoids having to resort to mathematical rebalancing of the IO tables.

The main data sources used to develop the splits in the national IO tables were the official statistics on the structure and activity of foreign-controlled affiliates for value added and gross output by industry, collected by the OECD in the Activity of Multinational Enterprises (AMNE) Database, and the official national statistics on Trade by Enterprise Characteristics (TEC) for merchandise exports and imports by industry and firm ownership (collected in the OECD TEC database). However, as explained below and in Sections 1, 2, and 3 of the Appendix, several practical and methodological challenges need to be addressed to integrate these datasets for this purpose. It is, for example, necessary to align differences in industry classifications, to estimate missing data (e.g., due to confidentiality), and, most importantly, to sensibly adjust for methodological and conceptual differences between the various sources.

National IO tables, with 34 industry breakdowns in ISIC Rev. 3 classification, were created by aggregating the inter-country IO tables that underpin the OECD-WTO TiVA databases ${ }^{11}$ for the years 2011-2014 (for a discussion on the advantages of using TiVA measures to study GVCs, see Suder et al., 2015). We chose this time period because TEC by ownership is available from 2011 onwards and AMNE is available up to and including 2014. The TEC database contains annual international trade in goods data broken down by industry (ISIC Rev. 4) and enterprise characteristics - including ownership (i.e., domestically controlled firms or foreign-controlled affiliates) - for 24 OECD and six non-OECD countries. National Statistical Offices develop TEC statistics by attributing trade flows to firms by merging international trade (usually customs) data with business registers via common business identifiers. The OECD AMNE database provides harmonized information on the structure and activity of foreign-controlled affiliates by industry (ISIC Rev. 4). The shares of foreigncontrolled affiliates and domestically controlled firms in value added and output were directly calculated from the database. ${ }^{12}$

AMNE and TEC statistics are both directly reported to the OECD and Eurostat by statistical offices, and are based on countries' official statistical business registers, enterprise surveys, and administrative records (including those from Customs Authorities), and provide statistical information on the complete population of firms of a given country. For instance, AMNE covered 19 million businesses across 19 countries for 2014 (further information about the data used for each country and year of the analysis is available upon request). Section 2 of the Appendix offers a detailed description of the estimation and imputation methods used to ensure the completeness of the data sources following standard methods. Section 3 of the Appendix describes the approach used to adapt the primary data to the accounting frameworks described by IO tables when (small, conceptual) inconsistencies occurred. 


\section{AN ILLUSTRATIVE APPLICATION}

Over the years, there has been considerable academic attention, also in IB, for the direct and indirect impact of foreign direct investment (FDI) and MNEs on host-country economic development, especially focused on developing countries (or the smaller subset of so-called emerging economies in which most FDI takes place) (for early work, see e.g., Caves, 1996; Meyer, 2004; Rodrik, 1999). Research has yielded insights into linkages and spillovers, with FDI as an important means to complement domestic savings, to transfer skills, knowledge and technology, improve competition, and increase the quantity and quality of employment (e.g., Jindra, Giroud, \& Scott-Kennel, 2009; Meyer \& Sinani, 2009; Zhang, Li, \& Li, 2014).

Despite these contributions, however, the empirical evidence on its exact consequences for host countries' economies is still far from conclusive. While initially partly due to the relative novelty of explicitly including MNEs and firm-specific behavior in such analyses, a proper assessment is hampered by persistent data availability problems, an issue that has become even more prominent with growing 'fine-slicing' across GVCs (Giroud \& Mirza, 2015; Kano, 2018; Narula \& Driffield, 2012). The illustrative application that we present next allows for a better understanding of the impact of MNEs, compared to domestic firms, also considering the second- and third-order effects, which could not be studied until now because of data limitations.

The IO tables extended with firm ownership that were created through the methodology and data outlined in the previous section can be used to calculate a variety of TiVA indicators for MNEs and domestic firms, including for example the import content of exports as well as the specific role of MNEs and domestic firms in value-added exports. These analyses allow us to shed new light on how firms, depending on their ownership, have engaged in GVCs over the 2011-2014 period for 19 OECD economies $^{13}$ and thus represent an illustrative example of how useful this novel methodology can be to investigate GVCs. This section presents these indicators, comparing the role of MNEs vis-àvis domestic firms across countries and industries.

First, the results of our analysis show that foreigncontrolled affiliates are less important in valueadded exports compared to their share in gross exports, as traditional measures suggest. Across the OECD countries for which data are available, foreign-controlled affiliates account on average for nearly half $(45 \%)$ of the total export value, despite accounting for only a very small percentage (1-5\%) of the number of firms in these countries. However, their importance in trade from a value-added perspective is much smaller: foreign-controlled affiliates account for only $31 \%$ of the exported value added (see Figure 1a). Hungary, Slovakia, and the Czech Republic are among the countries where the share of exports accounted for by foreigncontrolled affiliates is highest (over 70\%); their share in value-added exports is however 20 percentage points lower. Vice versa, domestically controlled firms (which may also be MNEs in their own right) play a much larger role in exports from a value-added perspective than can be observed in traditional trade statistics. This pattern holds across industries as foreign-controlled affiliates contribute less in value-added exports compared to their shares in gross exports in the vast majority of the industries considered in our analysis (Figure 1b).

The smaller contribution of foreign-controlled affiliates to value-added exports as compared to their importance in gross exports, which could be labeled as an 'MNE effect', is directly associated with their sourcing strategies: the import content of their exports is higher than that recorded for domestically controlled firms (see Figure 2) in all the countries included here. Figure 2 also provides the foreign content of exports by firm type after having removed the cross-country industry average (thus focusing on industry demeaned values) for each country, showing that our conclusion holds also when accounting for industry variations. Looking at the demeaned values, we not only observe variations across countries between domestic and foreign firms as to their foreign content of exports (relative to the industry mean), but also can still meaningfully interpret cross-country variation, i.e., the foreign content of exports is still higher in the Czech Republic than in Germany, for example. The differences are especially pronounced for those countries where MNEs are particularly important in international trade, and which are known as manufacturing hubs, such as the Czech Republic, Hungary, and Slovakia. While differences in the magnitude of the 'MNE effect' that we identified not only exist across countries but also across industries, the additional analysis reported in the Online Appendix (Table OA1 in Section 1) further corroborate that the domestic content of exports as a share of total exports (also known as VAX ratio) is on average lower for foreign-controlled affiliates 


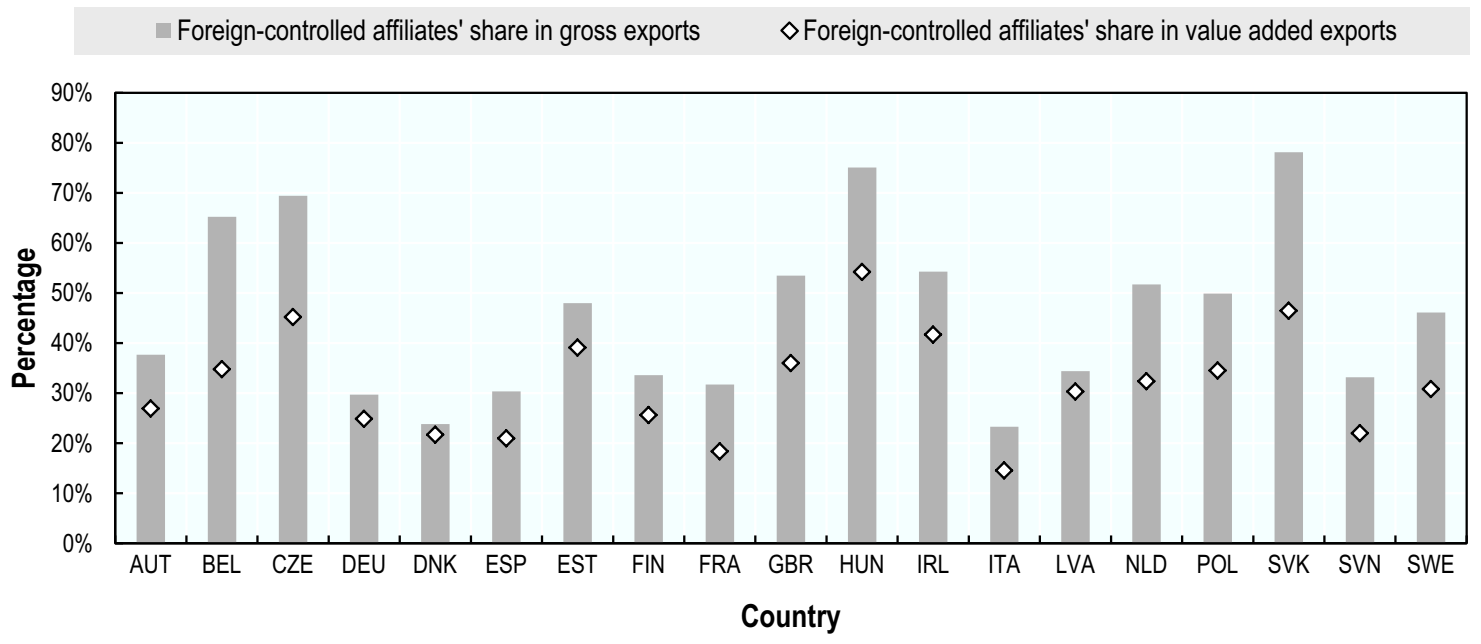

$\mathbf{a}$

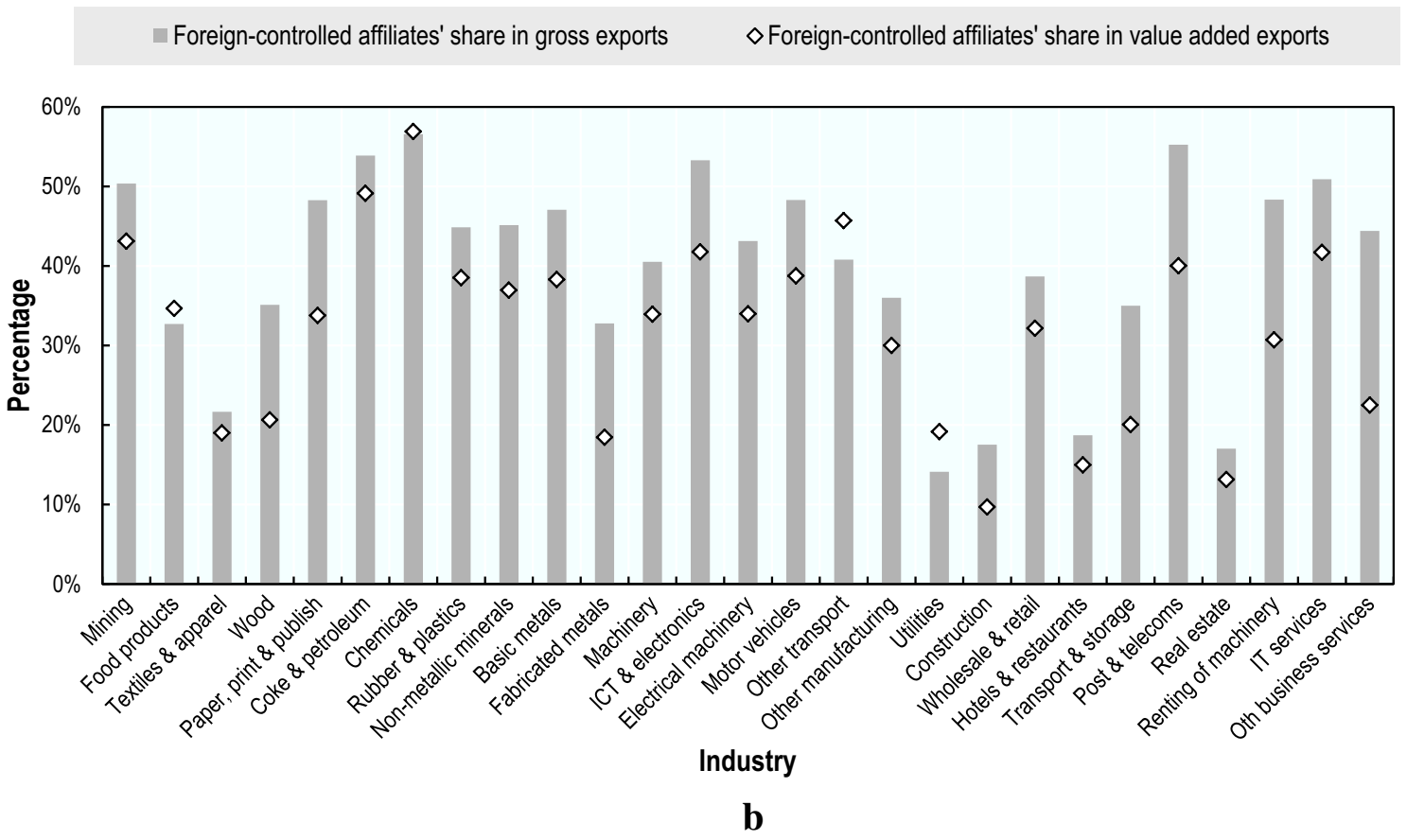

Figure 1 Foreign-controlled affiliates' share in gross exports and value-added exports, 2014. a By country, b by industry.

than for domestically controlled firms across a variety of industries considered in our application. This confirms that the results shown here are not industry-specific but rather generalizable across a variety of industrial compositions and settings.

A high import content of exports is typically seen as synonymous with a limited creation of local backward linkages to suppliers, as supplies need only be sourced once, either locally or internationally (Halaszovich \& Lundan, 2016; Havranek \&
Irsova, 2011; Meyer \& Sinani, 2009). An additional way to look at local linkages is not only to measure the immediate linkages that are created, but also to consider the full size of all indirect (upstream) value added that is created-i.e., the backward linkages to their suppliers, and their suppliers, and so on-as a share of their own, directly generated value added. Figure 3a shows this ratio of the indirect-to-direct value-added content of exports, essentially indicating the amount of USD in value added generated at 


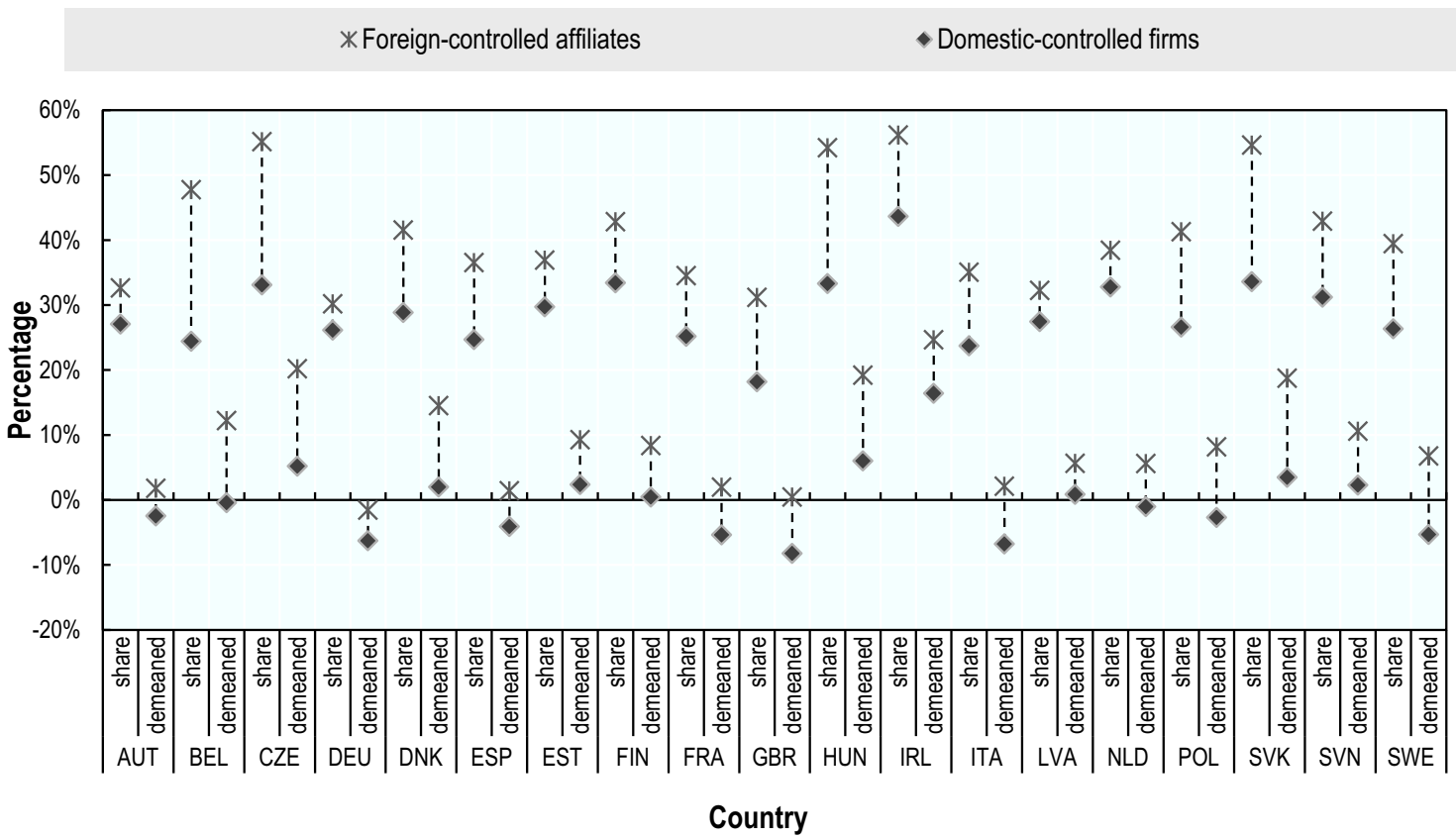

Figure 2 Foreign value-added content as a share of exports, 2014 (The demeaned value shown in the figure is obtained in the following way. For each industry, we calculated domestic-controlled firms' (or foreign-controlled affiliates') deviation from the industry mean (pooling data from all 19 countries covered in this study regardless of firm types) and then weighted these differences using exports to calculate the demeaned foreign content of exports as a share of total exports for each country).

upstream suppliers for each USD generated by the foreign- or domestically controlled firms themselves, across the countries included in our analysis. In the Nordics as well as in Ireland, foreigncontrolled affiliates create much fewer local linkages than domestic firms, whereas the opposite is the case for Central-Eastern European countries including Poland and Slovakia (and to a lesser extent the Czech Republic and Slovenia). In countries such as France, Italy, Latvia, The Netherlands, and the UK, foreign-controlled affiliates are very similar to domestically controlled firms in terms of their upstream impact. This is also confirmed by our cross-industry analysis shown in Figure 3b, which shows that the backward linkages created by foreign-controlled affiliates are very similar to those generated by domestic firms.

The results presented at the aggregated level are of course also determined by the sectoral composition of the domestic economy and foreign investors. For example, across the countries that we included, relatively high levels of backward linkage creation are observed for Food products, beverages and tobacco (C15T16) and Wood products (C20) - in most of the countries, 1 USD of direct value added generated due to exports in these industries generates more than 1 additional USD in upstream effects. In contrast, and as a function of the industry's relatively upstream position in value chains, foreign-controlled (and domestically controlled) firms in Fabricated metals (C28) typically generate fewer backward linkages.

Taken together, the findings in Figures 2 and 3 present a potentially paradoxical picture with respect to the role of foreign-controlled affiliates in host economies, and particularly the backward linkages that they create. On the one hand, we find a consistently higher import content of exports (and the mirror low domestic value-added share in exports) of foreign-controlled affiliates, which raises questions as to the extent to which these firms generate the local backward linkages that are considered one of the ways in which they can contribute to a domestic economy. However, Figure 3 suggests that with a few extreme exceptions, the degree of local linkages created is relatively similar between foreign-controlled affiliates and domestic firms - and that in Central-Eastern European countries, both the import content of exports and the extent of local linkage creation by foreigncontrolled affiliates is higher than that of domestic firms. As a concrete example, in the German motor 


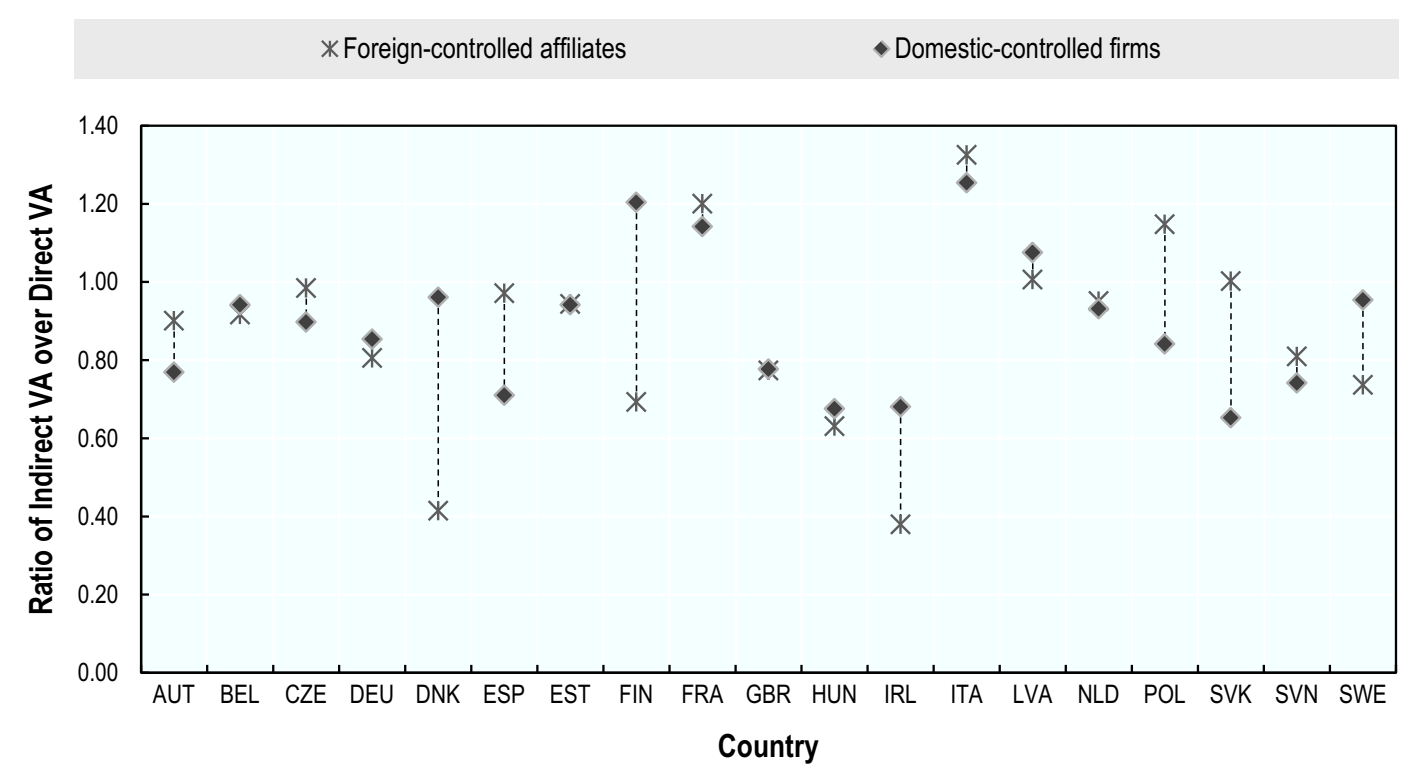

a

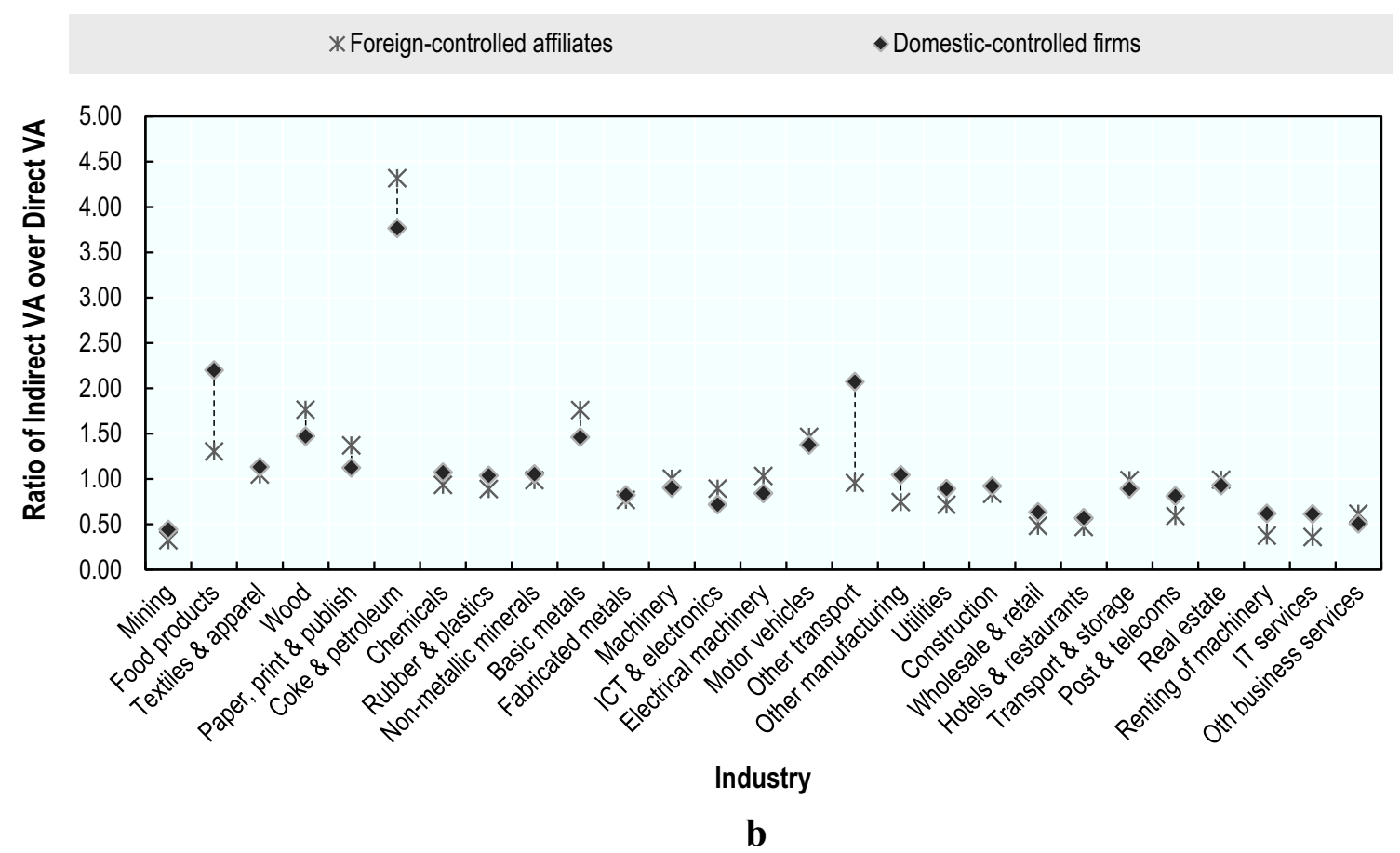

Figure 3 Backward linkage of firm's production by firm ownership, 2014 (The $Y$-axis corresponds to the ratio of indirect VA over direct VA content of exports). a By country, b by industry.

vehicle industry, foreign-controlled affiliates demonstrate a higher import content of exports (40\%) compared to domestic enterprises (32\%), whereas the ratio of the indirect-to-direct valueadded content of exports is higher, too (a factor of 1.47 compared to one of 1.17 for domestic enterprises). The same is true in many other industries and countries, including for example the computer and electronics, motor vehicles, and other transport equipment industries in the UK and France, or electrical machinery in Germany. This suggests that imports and local linkages are not mutually exclusive, but can go hand in hand, as a function of the much higher specialization of foreign-controlled 


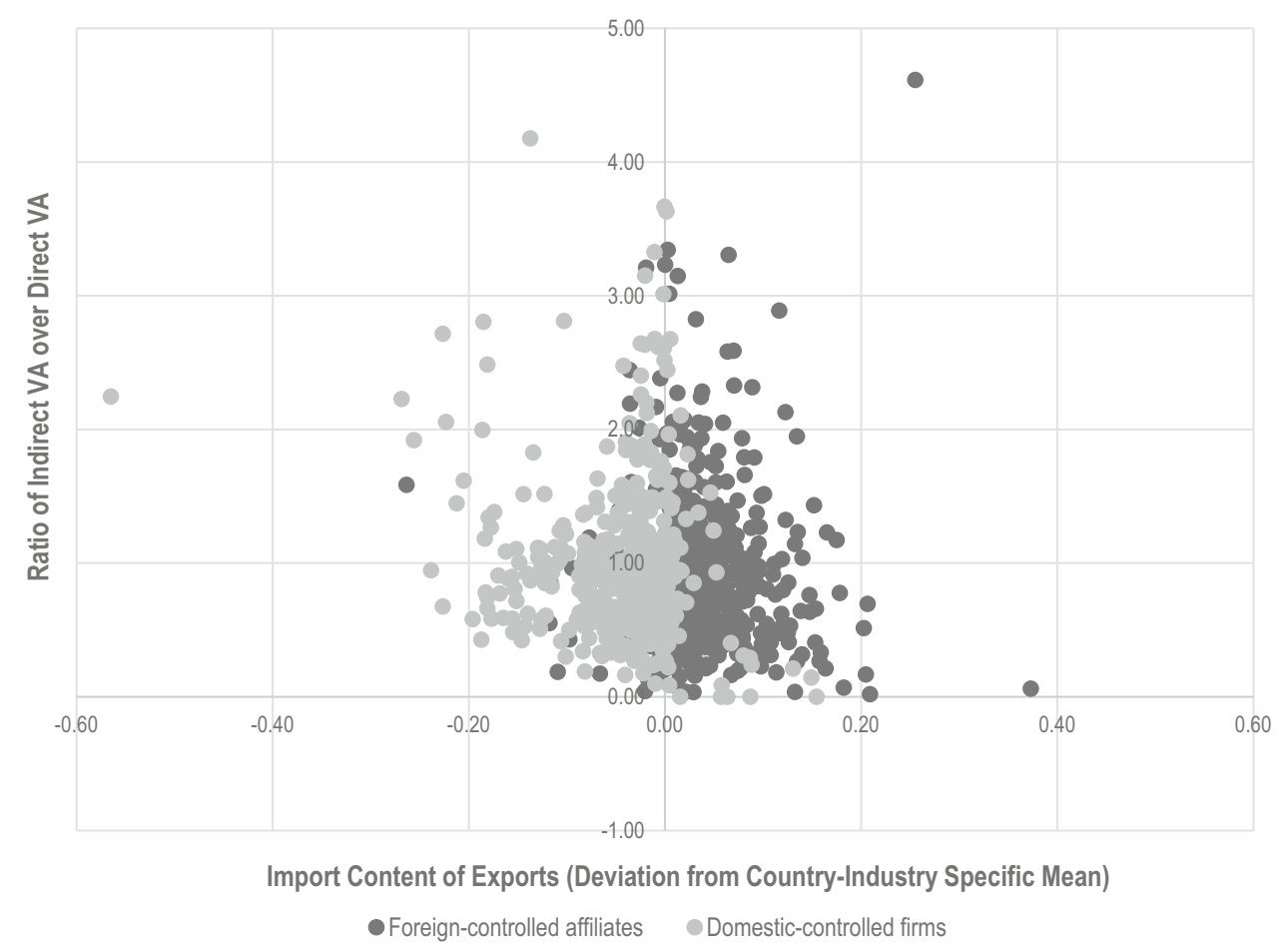

Figure 4 Correlation between import content and ratio of indirect-to-direct value-added content of exports removing countryindustry specific mean (We calculated domestic-controlled firms' (or foreign-controlled affiliates') deviation from the country-industry specific mean. This allows us to see if domestic-controlled firms' (or foreign-controlled affiliates') import content of exports is higher or lower than the country-industry average. Agriculture, Finance and Insurance, Public Administration, Education, Health, Other services, and Private household sectors are excluded from this table. For Agriculture, TEC export shares are used as proxies for value-added and gross outputs, and the VAX ratio would simply reflect this assumption. We did not further split by firm ownership the Public Administration, Education, Health, Other services, and Private household sectors as foreign-controlled affiliates count for only a little share. Finance and Insurance is also not split given its distinctive nature, the estimates using TEC statistics would not be suitable (for more details about data and imputation methods, see the preceding section and the Appendix). Zero shares are a consequence of the minimum corrections, which is seen as a sign of data inconsistency across various sources and are therefore also removed from this chart).

affiliates in only parts of the production process as compared to domestic firms ${ }^{14}$, resulting in much higher purchases as part of total output ${ }^{15}$.

Figure 4 plots the correlation between import content of exports and the ratio indirect-to-direct value-added content of exports after removing country-industry specific mean. It shows that there is clear evidence that foreign-controlled affiliates have a higher import content of exports whereas, when focusing on the ratio indirect-to-direct valueadded content of exports, foreign-controlled affiliates and domestic firms show a similar pattern. Figure 4 therefore corroborates that our conclusions also hold when accounting for industry differences and composition. Figure 5 further illustrates this for the manufacturing industries, showing that lower value-added-to-output ratios (i.e., firms purchase inputs instead of producing these themselves) are associated with only a moderately higher share of imported intermediates as opposed to domestically sourced ones, although the relationship is stronger for foreign-controlled affiliates than for domestic firms. ${ }^{16}$

Figure 6 presents the different export channels available to both domestically controlled firms and foreign-controlled affiliates to shed further light on this issue. Analyzing the shares of firms' exported value added that reaches foreign markets directly (i.e., firms export directly abroad), or indirectly (by supplying either domestically controlled firms or foreign-controlled affiliates that subsequently export), the graphs show that on average, across OECD countries, nearly $50 \%$ of the total exported value added of domestically controlled firms reaches foreign markets directly. Less than $25 \%$ is channeled through foreign-controlled affiliates, 


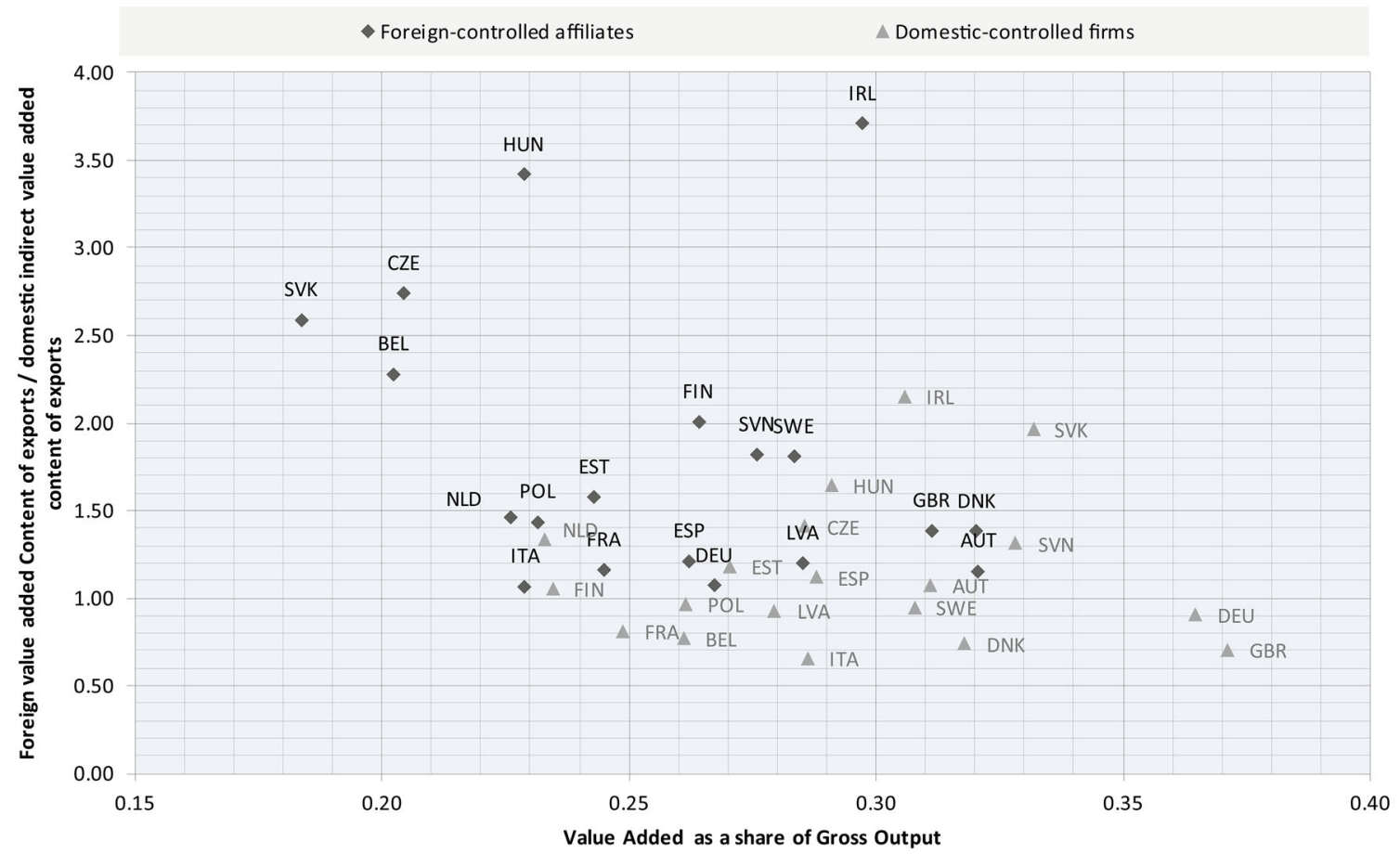

Figure 5 Domestic versus international linkages as a function of their value-added/gross output ratio, 2014 (The analysis is restricted to the manufacturing section which comprises units engaged in the physical or chemical transformation of materials, substances, or components into new products. It covers sectors 15-37 (in ISIC rev. 3), which represent 16 out of 34 industry breakdowns in the study).

which implies that, despite accounting for a relatively smaller share in total exports, domestically controlled firms are a more important conduit for other domestic firms to access foreign markets than foreign-controlled affiliates. Vice versa, foreigncontrolled affiliates export on average $70 \%$ of their value added directly to foreign markets, while domestically controlled firms (again) account for a larger share of the indirect exports than other foreign-controlled affiliates.

Section 2 of the Online Appendix reports a number of checks that we did to test the robustness of our findings.

\section{DISCUSSION AND CONCLUSION}

Prior studies examining GVCs have shed light on this increasingly dominant aspect of the IB landscape (Kano, 2018). Especially the ones utilizing data from IO models were able to capture important features of today's GVCs, as also noted by Suder et al. (2015). Yet, the industry-level nature of IO tables hindered our understanding of the role of firm heterogeneities and thus of how firms differ in their engagement in GVCs depending on their characteristics. We precisely tackled this issue by introducing a novel methodology adopted by the OECD that integrates not only country- and industry- but also firm-level analysis, thus providing IB scholars who investigate GVCs with the unique opportunity to undertake analyses that are extensive and yet fine-grained. As discussed in this note (and, in greater detail, in the accompanying Appendix), it specifically allows for a disaggregation of IO tables using established official data sources on linked trade and business statistics in a transparent manner, i.e., without having to resort to mathematical rebalancing of the IO tables.

To present the peculiarities of this new method and concurrently document its potential for the IB field, we also reported an illustrative application that aims at investigating the extent to which MNEs rely, both directly and indirectly, on foreign versus local suppliers, and in this way determine how MNEs (versus local firms) engage in GVCs and how such engagement varies across countries and industries. By focusing on a key firm characteristic firm ownership - and specifically looking at the idiosyncratic role of MNEs versus domestic firms in GVCs, our analysis thus captured important 


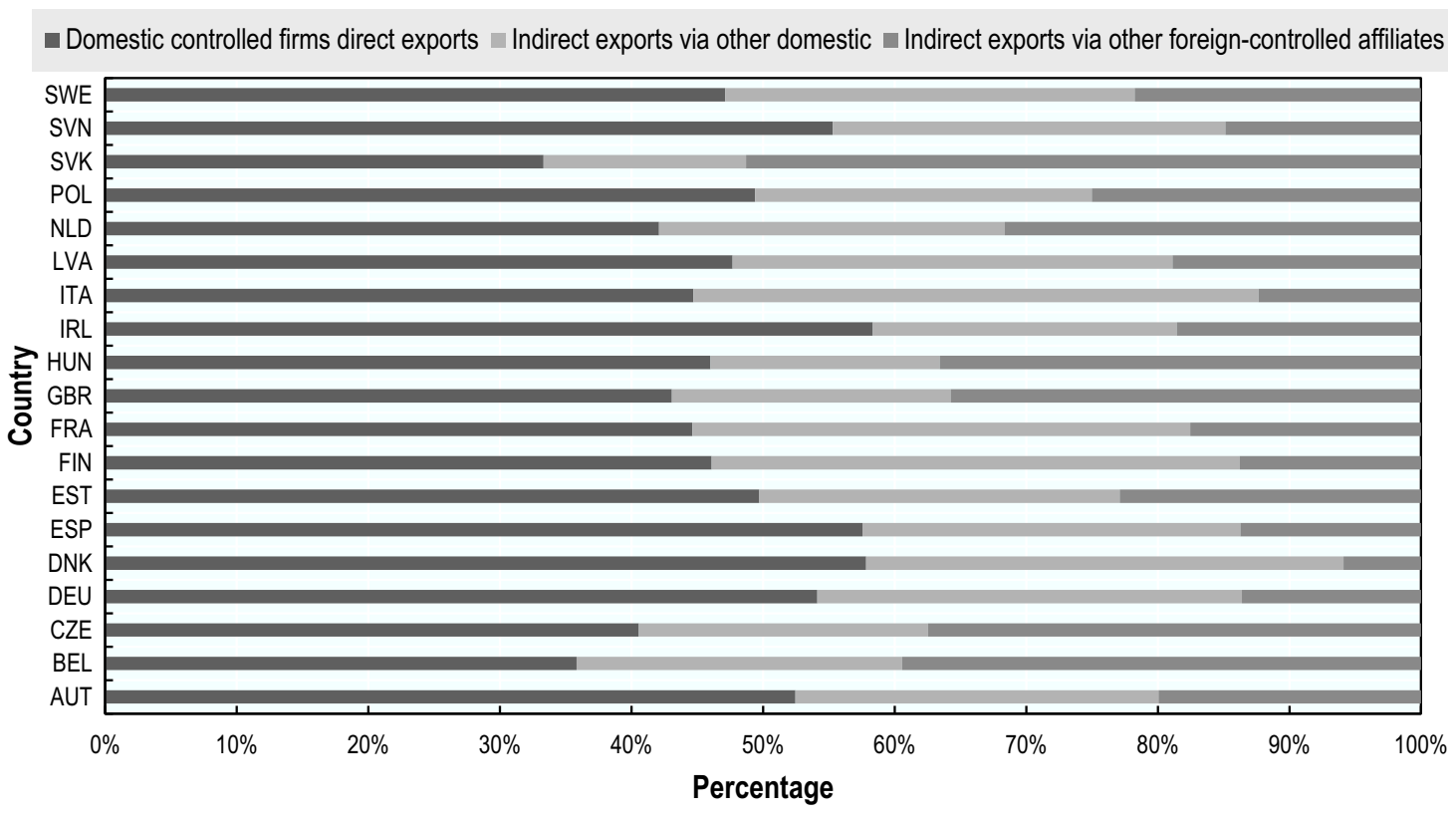

a

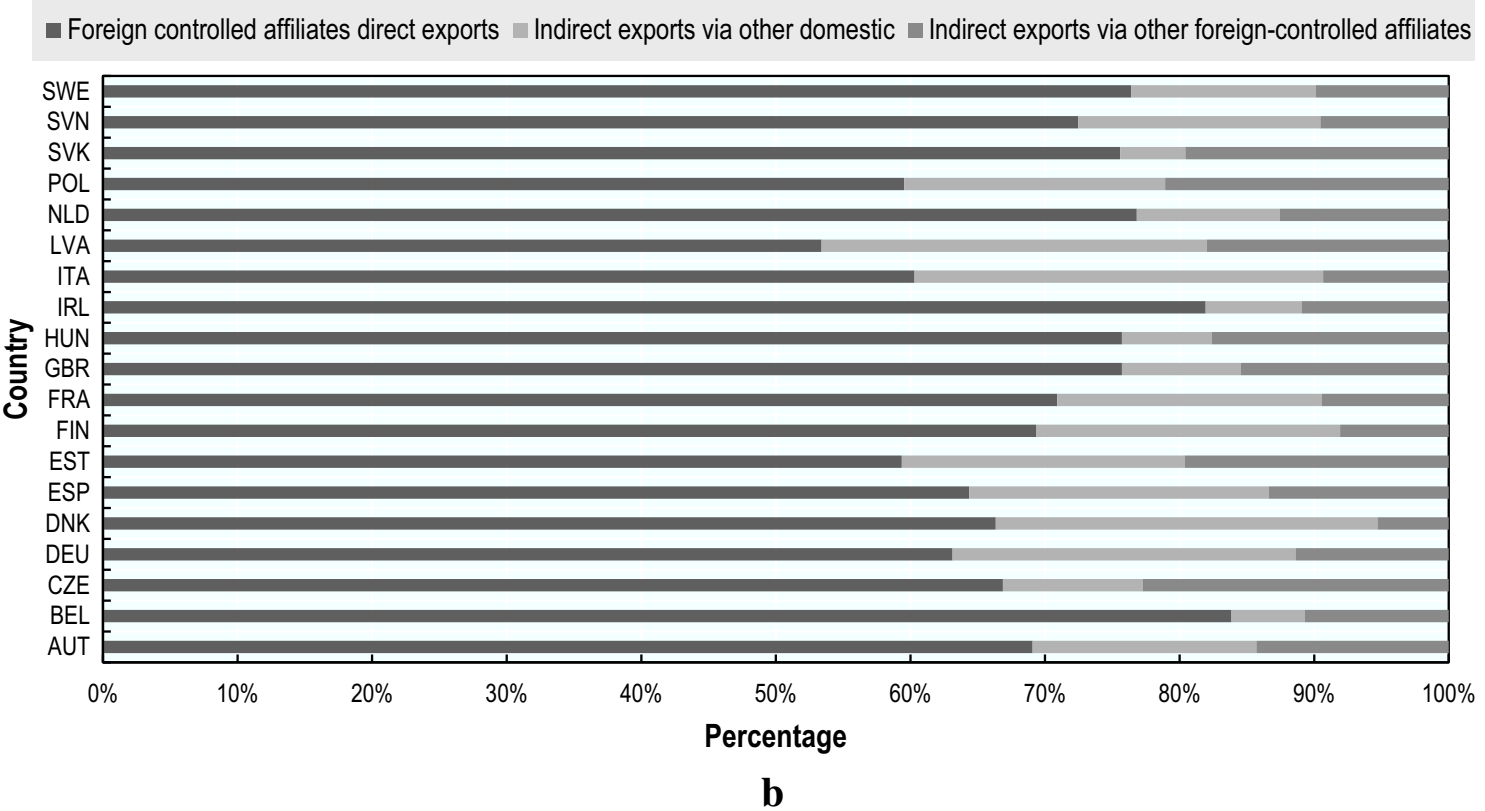

Figure 6 Export channels of domestic firms and foreign-controlled affiliates, 2014. a Domestically controlled firms, b foreigncontrolled affiliates

features of GVCs that could not be grasped up to now because of data limitations as discussed in the first part of this research note. While showing that foreign-controlled affiliates' contribution to valueadded exports is considerably smaller than what is suggested by traditional trade statistics (what we label as 'MNE effect'), our findings from the application of the novel methodology also, interestingly, show that the higher import content of exports of foreign-controlled affiliates can actually go hand in hand with the creation of local backward linkages.

Additionally, the cross-country analysis undertaken illustrates important variations across the 19 economies considered, thus generating further insights into the engagement of MNEs (versus 
domestic firms) in GVCs. Our cross-industry analysis similarly sheds new light on variations across the industry settings considered in our empirical setting while confirming our overall conclusions. Hence, the application of this novel methodology to the phenomenon of MNEs' participation in GVCs proves very useful to illustrate its potential to further our understanding of GVCs, corroborating the notion that the IB field can greatly benefit from the adoption of this new method. It also generates new important insights that provide an answer to relevant IB questions on MNEs' engagement in GVCs that we could not adequately address before due to data limitations.

An additional important contribution of this study involves the extensive tests for the robustness of the findings, as reported in the Online Appendix, and especially the sensitivity analysis which allows us to assess the reliability of the findings obtained through this new methodology. Stretching the assumptions that were made, by necessity, to disaggregate IO tables to their extremes, their impact on the key TiVA indicators by firm ownership was illustrated. While, as expected, the variation in assumptions had a negligible effect on the overall import content of exports for domestically controlled firms and foreign-controlled affiliates, greater variation was observed for the domestic intermediate use relationships between different types of firms - even if the overall conclusions reported in this research note were not affected.

The challenges for statistical offices in developing the data that would allow the analyses to move beyond these assumptions are being recognized by the OECD Committee of Statistics and Statistical Policy, which has established an Expert Group on this topic with subject matter specialists from national statistical offices. This indicates a strong potential that more data, for more countries, will become available in the near future, also for use by IB scholars, to support the types of analyses presented in this note. Information on how businesses provide intermediate inputs to other firms forms the foundation for such more precisely disaggregated intermediate use matrices, as well as linked micro datasets. A further step that the OECD intends to make is to also include more detailed partner dimensions in these extended tables, to allow for an (improved) integration of extended SU and IO tables into global SU tables, and thus examine the differences in the geographical spread of different types of firms' engagement in GVCs (see OECD \& Statistics Denmark, 2017, for an example).
While our illustrative application focused on a 4-year time period and presented some key findings related to the most recent year for which data is currently available (2014), we note here that, as data covering additional years becomes available, future work embracing this new methodology will really be able to leverage the longitudinal aspect to then generate new important insights into how GVCs change over time. Such follow-up studies might improve our understanding of the role of individual countries and specific firm typologies in these GVC configurations, and thus contribute to a much more nuanced picture of this important phenomenon in today's global economy. Moreover, as soon as it will be possible to split data on exports identifying the industry of origin and the country of destination by firm type, scholars will have the opportunity to move to truly multicountry analyses that can shed new light on how GVCs are organized.

As national statistics offices of OECD countries are working towards the creation of datasets that also allow for combined splits, i.e., using more than one firm dimension at a time, we expect that in the near future it will also be possible to examine the combined effect of specific firm dimensions, for instance by looking at firm ownership and firm size to identify four different categories of firms and unveil their specific contributions to GVCs. This seems a particularly relevant avenue for future research as an in-depth examination of combined firm effects including size would unveil important features of the nature and configuration of GVCs, especially in view of the growing involvement of small and medium-sized MNEs in international supply networks. To offer a practical overview of both current and future data-related options available to IB researchers, Section 3 of the Online Appendix lists datasets that will hopefully become available in the near future as well or are already retrievable, with website links to the national statistics offices of the OECD countries through which IB scholars may connect with them to obtain access to apply the methodology that we introduced in this research note.

Since the focus of this note was methodological, the empirical analysis presented in our illustrative application has been merely descriptive. However, it is possible to further analyze the rich set of GVC indicators that can be constructed now - by country, industry, and firm type - in combination with traditional areas of IB interest. The role of MNEs in GVCs described in our application require further 
and more formal explanations by, for example, considering how locational advantages, international trade and investment treaties, cultural or institutional distance, or industry-specific factors related to inter alia technology intensity, trade openness or concentration levels have an impact on various dimensions of GVC integration. In addition, the indicators measuring the ways in which MNEs are engaged in GVCs can be considered as a driver of other important processes, including economic growth or upgrading, and in relation to productivity, employment, and wages.

Finally, in our view, there are now already considerable opportunities for using the novel methodology presented here to account for other sources of firm heterogeneity beyond the one we used as illustrative application, i.e., firm ownership. An interesting area for further investigation would be to focus on R\&D intensity and, more broadly, the different levels of innovativeness of firms participating in GVCs, thus looking at differences with respect to not only their R\&D expenditures but also their technological payments in relation to, for example, patents and trademarks. Analyses concerning this type of firm-level idiosyncrasies have the potential to shed new light on the key role of more (versus less) innovative firms in the formation and configuration of GVCs in the global economy and thus advance IB research on this topic. All the above-mentioned avenues for future research clearly corroborate that this novel methodology has the potential to greatly enhance our understanding of how different firm characteristics well beyond firm ownership play a role in GVCs.

\section{ACKNOWLEDGEMENTS}

The authors thank Nadim Ahmad, Head of Division at the OECD, for his helpful guidance and comments, and the participants of the OECD Expert Group on Extended SUTs, the contributors to the various Regional Trade in Value Added Initiatives including those of APEC, Europe (Eurostat Figaro) and North America, and of the OECD Working Party on Trade in Goods and Services Statistics, and the OECD Working Party on National Accounts Statistics for the productive discussions on previous versions of this work.

Open Access This article is distributed under the terms of the Creative Commons Attribution 4.0 International License (http:// creativecommons.org/licenses/by/4.0/), which permits unrestricted use, distribution, and reproduction in any medium, provided you give appropriate credit to the original author(s) and the source, provide a link to the Creative Commons license, and indicate if changes were made.

\section{NOTES}

${ }^{1}$ Various terms have been coined to discuss and contextualize this important feature of economic globalization - e.g., "global factory" (Buckley, 2011), "global supply chains," and "offshoring", to name a few. For a comprehensive review of studies on the offshoring of service activities, see e.g., Pisani and Ricart (2016).

${ }^{2}$ We emphasize here that these three research tools present important differences amongst themselves and can be used, in combination or separately, to address a variety of research questions. Enterprise surveys and international trade statistics are primary data. IO modeling is a method that relies on IO tables that are in essence numeric/ statistical models of reality in a way that primary data (trade statistics from e.g., customs records and business surveys) are not. As also discussed in detail in the manuscript, the novel methodology presented here focuses on the extension of IO models (using of course international trade statistics) to look more carefully at international transactions by relying on firm-level information.

${ }^{3}$ For more detailed information on (primarily national) IO models, see the seminal work by Leontief (1966), and the more recent one by Miller and Blair (2009).

${ }^{4}$ The OECD AMNE data collection, like the similar data collection by Eurostat, differentiates between "foreign-controlled affiliates" and "domestically controlled firms.". An enterprise is classified as foreign-controlled when a foreign owner holds more than $50 \%$ of its capital, i.e., the majority of ordinary shares or voting power. In this paper, we use "foreign-controlled affiliate," "foreign-controlled firm," and "MNE" interchangeably as they are all intended to refer to the previously identified typology of firms. Conversely, a firm is classified as domestically controlled when a domestic owner holds more than $50 \%$ of its capital; for this type, we use "domestically controlled firm," "domestic-controlled firm," and "domestic firm" interchangeably.

${ }^{5}$ Prior IB work has covered a wide range of topics associated with this important phenomenon, ranging from the potential positive effects associated with MNEs' role in the improvement of local institutions (e.g., Cantwell, Dunning, \& Lundan, 
2010) to the potential productivity advances of domestic firms which may benefit from knowledge spillovers from MNEs' affiliates (e.g., Meyer \& Sinani, 2009) or the positive vertical linkage effects generated by their presence (e.g., Liu, Wang, \& Wei, 2009). Obviously, this debate is beyond the scope of this methodology research note which just uses the distinction between MNEs and domestic firms as illustrative application.

${ }^{6}$ Although as yet, and despite the fact that these measures can be very useful in understanding IB issues, take-up among IB scholars of this work has so far been marginal, as also noted by Suder et al. (2015).

${ }^{7}$ http://www.wiod.org/project.

${ }^{8} \mathrm{http}: / /$ www.oecd.org/trade/measuring-trade-invalue-added.htm. In addition, and to further reinforce these major efforts, recent years have seen the initiation of complementary regional initiatives such as the Eurostat FIGARO project (for additional information, see http://ec.europa.eu/eurostat/web), APEC TiVA (http://www.apectivagvc.org/), and North American TiVA (https://www.usitc.gov/).

${ }^{9} \mathrm{~A}$ first change that was introduced includes an adjustment for wholesalers and retailers. In merchandise trade statistics linked to the business register (the TEC data) it is not uncommon that more than half of imports and exports are attributed to wholesalers and retailers (including wholesale and retail units of larger manufacturing MNEs). To enhance their relevance, National Accounts statistics consider such industries as margin-producing industries and reroutes trade flows to the industries that actually use the imported products in their production, or produce the exported products. Not mirroring this rerouting means distorting the geographical and product distribution of trade of both wholesale and retail, and of manufacturing industries. The wholesale adjustment that we introduce is explained in detail in the enclosed Appendix. Other adjustments include a fine-tuned assessment of the services sector and public/government sectors, in light of amongst others additional data availability (STEC, notably). The sensitivity analysis reported in the robustness checks (see the Online Appendix) is another important new feature of the methodology presented in our note as it allows for a more in-depth assessment of the reliability of the results obtained, as also discussed in our concluding remarks. Finally, the inclusion of multiple years beyond the 2011 data used by Piacentini and Fortanier (2015) allows for year-to-year comparisons as well as new analyses such as the sensitivity analysis just mentioned.

${ }^{10}$ Small adjustment rows for taxes and subsidies on products, and to avoid double counting of transport and insurance services provided by residents on imports, are also included.

${ }^{11}$ Using the SNA 1993 based version, including now-cast tables, to better capture the cross-border movement of goods in GVCs.

${ }^{12}$ Among the variables in AMNE, the production value and value added at factor cost mostly resemble the national accounts definitions for output and value added respectively. If the production value was not reported, turnover was used. If value added at factor cost was not reported, gross operating surplus was used as proxy.

${ }^{13}$ We focus our illustrative application on 19 selected OECD countries and in the main text report the findings related to 2014 (the most recent year for which data is currently available) as a suitable example of the type of analyses that can be performed. The sensitivity analysis included in the Online Appendix (see its Section 2) covers the whole 2011-2014 period and thus well illustrates the potential to undertake longitudinal studies. We also note here that, while Piacentini and Fortanier (2015) also discuss firm ownership as a potential firm heterogeneity in their exploratory work using 2011 data, their main focus is on firm size, specifically the difference between small and large firms.

${ }^{14}$ Multinationals have long been seen as responsible for the cross-border slicing up of value chains through the establishments of their units in different countries, each specializing in particular stages of a good's (or service's) production sequence (Hummels, Ishii, \& Yi, 2001). This increased segmentation has been corroborated in recent literature, e.g., on agglomeration economics (Alcácer, Cantwell, \& Piscitello, 2016; Alfaro \& Chen, 2014). This literature also suggests that as a result of their greater need for, and higher potential to derive benefits from sourced inputs, affiliates of MNEs are significantly more agglomerative than domestic enterprises.

${ }^{15}$ Our data indicate that across OECD countries, purchases account for $\sim 70 \%$ of total output for foreign affiliates; while for domestic enterprises this is $60 \%$.

${ }^{16}$ Our findings cannot exclude the possibility that foreign-controlled affiliates specialize in more downstream activities than domestic firms within 
the same industry. It is however not possible to verify this empirically. This is because in official statistics (and in many other sources) firms are classified to (detailed) industries based on the product that forms the majority of their output, meaning that, by definition, 'at their point of sale' both foreigncontrolled and domestic firms are 'equal' in terms of their up- or downstreamness - even though their business models on how to produce that particular product in terms of how much is produced inhouse and how much is outsourced may indeed

\section{REFERENCES}

Ahmad, N., Araújo, S., Lo Turco, A., \& Maggioni, D. 2011. Using trade microdata to improve trade in value-added measures, proof of concept using Turkish data. OECD statistics directorate working paper no. 2011/16.

Ahmad, N., Bohn, T., Mulder, N., Vaillant, M., \& Zaclicever, D. 2017. Indicators on global value chains: A guide for empirical work. OECD statistics directorate working paper no. 2017/08.

Ahmad, N., \& Ribarsky, J. 2014. Trade in value added, jobs and investment. Paper presented at the IARIW general conference, Rotterdam, The Netherlands.

Alcácer, J., Cantwell, J., \& Piscitello, L. 2016. Internationalization in the information age: A new era for places, firms, and international business networks? Journal of International Business Studies, 47(5): 499-512.

Alfaro, L., \& Chen, M. X. 2014. The global agglomeration of multinational firms. Journal of International Economics, 94(2): 263-276.

Andersson, U., Dasi, A., Mudambi, R., \& Pedersen, T. 2016. Technology, innovation and knowledge: The importance of ideas and international connectivity. Journal of World Business, 51(1): 153-162.

Bernard, A. B., Jensen, J. B., Redding, S. J., \& Schott, P. K. 2007. Firms in international trade. Journal of Economic Perspectives, 21(3): 105-130.

Buckley, P. J. 2011). International integration and coordination in the global factory. Management International Review, 51(2): 269-283.

Bunyaratavej, K., Hahn, E. D., \& Doh, J. P. 2007. International offshoring of services: A parity study. Journal of International Management, 13(1): 7-21

Bunyaratavej, K., Hahn, E. D., \& Doh, J. P. 2008. Multinational investment and host country development: Location efficiencies for services offshoring. Journal of World Business, 43(2): 227-242.

Cantwell, J., Dunning, J. H., \& Lundan, S. M. 2010. An evolutionary approach to understanding international business activity: The co-evolution of MNEs and the institutional environment. Journal of International Business Studies, 41(4): 567-586.

Caves, R. E. 1996. Multinational Enterprise and Economic Analysis. Cambridge: Cambridge University Press.

Chong, S., Van Beveren, I., Verbiest, P., \& Van der Wal, R. 2016. An 10 table for SMEs and large enterprises. The Hague: Statistics Netherlands.

Cuervo-Cazurra, A., Mudambi, R., \& Pedersen, T. 2018. The boundaries of the firm in global strategy. Global Strategy Journal, 8(2): 211-219.

De la Cruz, J., Koopman, R., Wang, Z., \& Wei, S. J. 2010. Estimating foreign value-added in Mexico's manufacturing exports. USITC working paper. (and does) vary. Because the industry classification that has been used in our work is relatively coarse (2-digit categories), it is possible that within an individual 2-digit category, foreign-controlled firms may be more active in a relatively more downstream 4-digit subcategory, and domestic firms in a relatively more upstream 4-digit subcategory (or vice versa). While these further analyses cannot be performed as of today, we hope that the availability of finer-grained data will allow them in the future.

Demirbag, M., \& Glaister, K. W. 2010. Factors determining offshore location choice for R\&D projects: A comparative study of developed and emerging regions. Journal of Management Studies, 47(8): 1534-1560.

Doh, J. P., Bunyaratavej, K., \& Hahn, E. D. 2009. Separable but not equal: The location determinants of discrete services offshoring activities. Journal of International Business Studies, 40(6): 926-943.

Dutt, P., Mihov, I., \& Van Zandt, T. 2013. The effect of WTO on the extensive and the intensive margins of trade. Journal of International Economics, 91(2): 204-219.

Fetzner, J., \& Strassner, E. 2015. Identifying heterogeneity in the production components of globally engaged business enterprises in the United States. Washington: US Bureau of Economic Analysis.

Fung, H.-G., Yau, J., \& Zhang, G. 2011. Reported trade figure discrepancy, regulatory arbitrage, and round-tripping: Evidence from the China-Hong Kong trade data. Journal of International Business Studies, 42(1): 152-176.

Giroud, A., \& Mirza, H. 2015. Refining of FDI motivations by integrating global value chains' considerations. Multinational Business Review, 23(1): 67-76.

Grossman, G. A., \& Rossi-Hansberg, E. 2008. Trading tasks: A simple theory of offshoring. American Economic Review, 98(5): 1978-1997.

Hahn, E. D., Bunyaratavej, K., \& Doh, J. P. 2011. Impacts of risk and service type on nearshore and offshore investment location decisions. Management International Review, 51(3): 357-380.

Halaszovich, T. F., \& Lundan, S. M. 2016. The moderating role of local embeddedness on the performance of foreign and domestic firms in emerging markets. International Business Review, 25(5): 1136-1148.

Havranek, T., \& Irsova, Z. 2011. Estimating vertical spillovers from FDI: Why results vary and what the true effect is. Journal of International Economics, 85(2): 234-244.

Hummels, D., Ishii, J., \& Yi, K. M. 2001. The nature and growth of vertical specialization in world trade. Journal of International Economics, 54(1): 75-96.

Hummels, D., Jørgensen, R., Munch, J., \& Xiang, C. 2014. The wage effects of offshoring: Evidence from Danish matched worker-firm data. American Economic Review, 104(6): 1597-1629.

INEGI. 2017. Valor agregado de exportación de la manufactura global. Aguascalientes: INEGI.

lindra, B., Giroud, A., \& Scott-Kennel, J. 2009. Subsidiary roles, vertical linkages and economic development: Lessons from transition economies. Journal of World Business 44(2): 167-179.

Johnson, R. C., \& Noguera, G. 2012. Accounting for intermediates: Production sharing and trade in value added. Journal of International Economics, 86(2): 224-236. 
Kano, L. 2018. Global value chain governance: A relational perspective. Journal of International Business Studies, 49(6): 684-705.

Kee, H. L., \& Tang, H. W. 2016. Domestic value added in exports: Theory and firm evidence from China. American Economic Review, 106(6): 1402-1436.

Koopman, R., Wang, Z., \& Wei, S. J. 2012. Estimating domestic content in exports when processing trade is pervasive. Journal of Development Economics, 99(1): 178-189.

Koopman, R., Wang, Z., \& Wei, S. J. 2014. Tracing value-added and double counting in gross exports. American Economic Review, 104(2): 459-494.

Leontief, W. 1966. Input-output economics. New York: Oxford University Press.

Liu, X. M., Wang, C. G., \& Wei, Y. Q. 2009. Do local manufacturing firms benefit from transactional linkages with multinational enterprises in China? Journal of International Business Studies, 40(7): 1113-1130.

Lopez-González, J. 2017. Mapping the participation of ASEAN small- and medium-sized enterprises in global value chains. OECD trade policy papers 203.

Meyer, K. E. 2004. Perspectives on multinational enterprises in emerging economies. Journal of International Business Studies 35(4): 259-276.

Meyer, K. E., \& Sinani, E. 2009. When and where does foreign direct investment generate positive spillovers? A meta-analysis. Journal of International Business Studies, 40(7): 1075-1094.

Miller, R. E., \& Blair, P. D. 2009. Input-Output Analysis: Foundations and Extensions. Cambridge: Cambridge University Press.

Mudambi, R. 2008. Location, control and innovation in knowledge-intensive industries. Journal of Economic Geography, 8(5): 699-725.

Narula, R., \& Driffield, N. 2012. Does FDI cause development? The ambiguity of the evidence and why it matters. The European lournal of Development Research, 24(1): 1-7.

OECD. 2019. OECD SME and Entrepreneurship Outlook 2019. Paris: OECD.

OECD \& Statistics Denmark. 2017. Nordic countries in global value chains. Copenhagen: Statistics Denmark.

OECD \& World Bank Group. 2015. Inclusive global value chains, policy options in trade and complementary areas for GVC integration by small and medium enterprises and low income developing countries. In G20 trade ministers meeting. Istanbul, Turkey.

OECD \& WTO. 2011. Trade in value-added: Concepts, methodologies and challenges. Paris \& Geneva: OECD \& WTO. http:// www.oecd.org/sti/ind/49894138.pdf.

Piacentini, M. \& Fortanier, F. 2015. Firm heterogeneity and trade in value added. OECD STD/CSSP/WPTCS vol. 23.

Pisani, N., \& Ricart, J. E. 2016. Offshoring of services: A review of the literature and organizing framework. Management International Review, 56: 385-424.

Rodrik, D. 1999. Trade policy and economic growth: A skeptic's guide to cross-national evidence. CEPR discussion paper 2143.

Saborío, G. 2015. An extended supply-use table. Costa Rica: Banco Central de Costa Rica.

Suder, G., Liesch, P. W., Inomata, S., Mihailova, I., \& Meng, B. 2015. The evolving geography of production hubs and regional value chains across East Asia: Trade in value-added. Journal of World Business, 50(3): 404-416.

The Economist. 2013. Here, there and everywhere: January 19th (pp. 1-16).

Timmer, M. P., Dietzenbacher, E., Los, B., Stehrer, R., \& de Vries, G. J. 2015. An illustrated user guide to the world input-output database: The case of global automotive production. Review of International Economics, 23: 575-605.

Turkina, E., Van Assche, A., \& Kali, R. 2016. Structure and evolution of global cluster networks: Evidence from the aerospace industry. Journal of Economic Geography, 16(6): 1211-1234.

Yang, C., Chen, X., Duan, Y., Jiang, X., Pei, J., Xu, J., Yang, L., \& Zhu, K. 2013. Measurement of trade in value-added: Using Chinese input-output tables capturing processing trade. Proceedings of the 59th ISI World Statistics Congress, Hong Kong (Session STS024). http://2013.isiproceedings.org/Files/ STS024-P3-S.pdf.

Zhang, Y., Li, Y., \& Li, H. Y. 2014. FDI spillovers over time in an emerging market: The roles of entry tenure and barriers to imitation. Academy of Management Journal, 57(3): 698-722.

\section{APPENDIX ${ }^{1}$}

\section{Section 1: Disaggregating a National IO Table by Firm Characteristics}

In what follows, we describe in detail the five core steps, introduced by Piacentini and Fortanier (2015) in their exploratory work and now used by the OECD, that are involved in the transformation required to disaggregate a national IO table by firm characteristics. To visualize the difference, Fig. 7 shows the structure of a typical national IO table, and Fig. 8 the structure of a national IO table with splits by firm characteristics, which in our study consists of the distinction between domestically controlled firms and foreign-controlled affiliates.

Step 1. Disaggregating IO columns: Industry value added and gross output. The first step towards disaggregating the IO table by firm characteristics is to break down the activity columns. In order to achieve this, value added and output by industry are split using the share of foreign-controlled affiliates in total value added, and in total gross outputs derived from AMNE. Before moving forward, it is important to highlight the few key assumptions made when adopting this methodology. First, the combination of AMNE and IO data presupposes consistency between the two. However, this is not typically the case in reality. Partly, this reflects the coverage of non-observed activities, which are usually not included in AMNE data but are estimated in the national accounts. Another source of difference is reflected in the statistical units used in constructing the different datasets, i.e., 'enterprises' in AMNE versus 'establishments' in IO tables. ${ }^{2}$ Third, non-market activities are not typically covered in AMNE data. As such, in the 


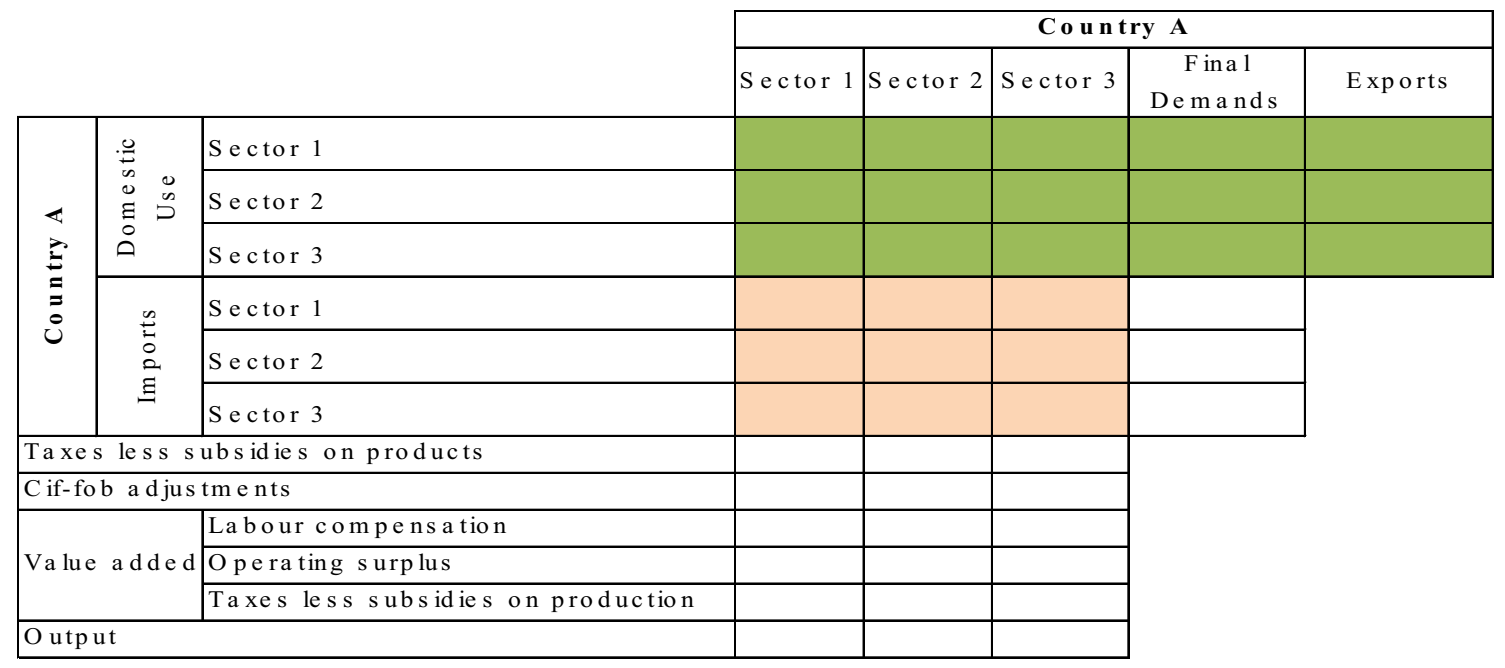

Figure 7 Structure of a typical national IO table.

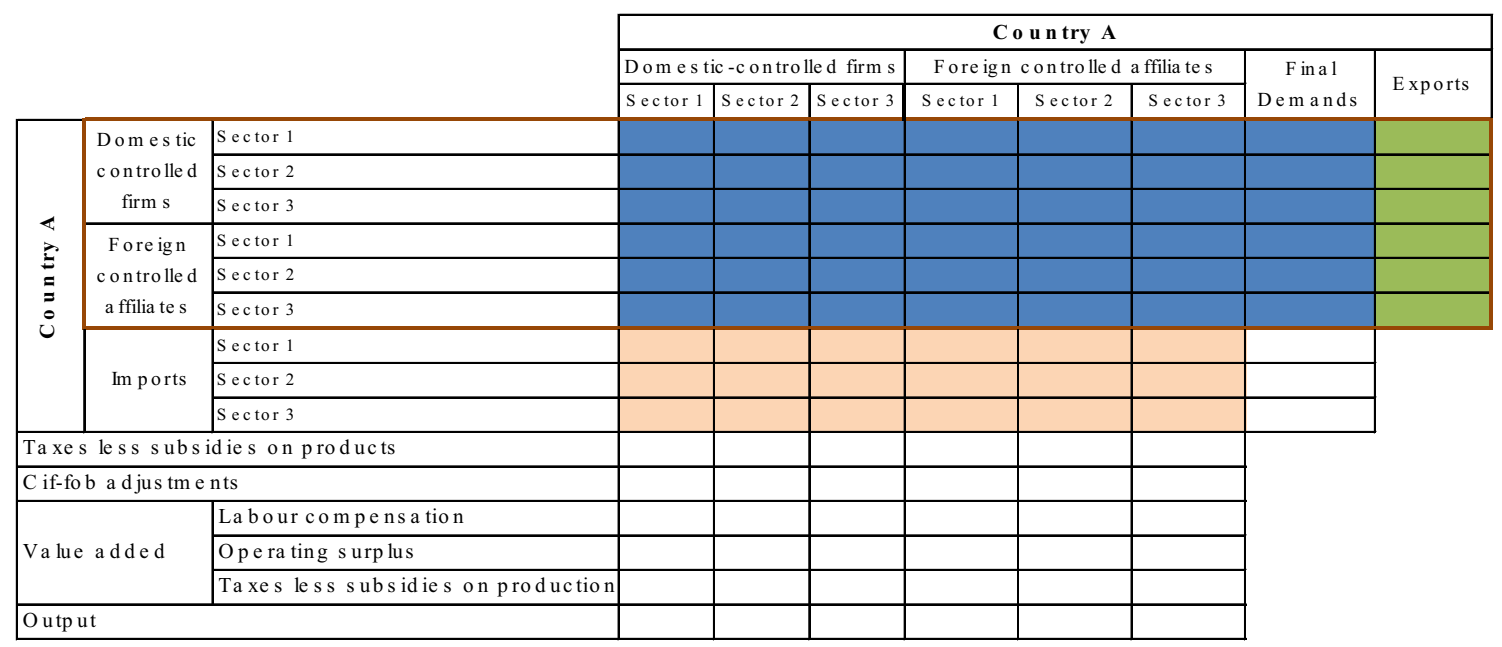

Figure 8 IO table with splits by firm heterogeneity.

analysis that follows, activities with significant non-market output (e.g., public administration services, health, education, and other social services) are excluded, which implies that these industries are not broken down by types of enterprise (foreign and domestic controlled), but treated separately (since in most OECD countries, the private sector plays a limited role in public administration services, this does not impact the relevance of the analysis). Similarly, estimates of owner-occupied dwelling services are removed from the category of real-estate activities and included in non-market activities. Finally, no heterogeneity breakdowns are provided for the financial services sector because AMNE data for this sector are typically confidential.
Step 2. Disaggregating 10 columns: Imports. The next step involves splitting the industry columns of the import matrix (which records imports of products by using industries) by firm type. This is achieved using information available in the TEC database. The starting point is information on the value of total 'direct' imports by domestically controlled firms and foreign-controlled affiliates. However, as also noted in footnote 9 in the paper, many firms import 'indirectly' via wholesale intermediaries. Therefore, estimates of 'direct' imports for nonwholesale goods traders are complemented with estimates of 'indirect' imports to derive the overall shares of imports in each industry by domestically controlled firms and foreign-controlled affiliates (see Box 1 for a further explanation). 
Box 1 Wholesale adjustment for imports.

In IO tables, following the System of National Accounts, imports by firms are included as direct imports even if they pass through resident wholesale and retail industries first. In other words, imports of goods by wholesalers and retailers for subsequent sale without any further processing are not recorded as their imports in the SNA. The same holds for exports of goods that have not been the subject of any further processing by wholesalers and retailers.

By contrast, in TEC statistics, trade is matched to those firms that are immediately responsible for imports and exports - including by wholesale and retail firms themselves. Compared to the national accounts data, this results in a strong overestimation of trade by this industry and a strong underestimation of trade by all others. It is not uncommon for wholesale and retail enterprises to account for half of international trade flows. To align with national accounts concepts, the TEC export and import values for the wholesale and retail industry were therefore constrained to the levels reported in national IO tables.

The additional trade was subsequently distributed to other sectors in a two-stage procedure by first identifying the products involved (using TEC statistics on trade by product for the wholesale industry, converting the CPC classifications to the ISIC classification used in the symmetric IOs) and then proportionately allocating these products to using (importing) or exporting industries and firm types on the basis of information included in TEC and national IO tables.

Since no further information is available about the types of products that are imported by domestically controlled firms and foreign-controlled affiliates, this ratio is applied across all imported products within an industry. In other words it assumes that, within an industry, domestically controlled firms import the exact same product basket as foreign-controlled affiliates. An important caveat is that TEC statistics only reflect merchandise trade, and not services trade. For manufacturing industries, this will likely not generate major biases, but it is more problematic for firms in the services industry. Therefore, a slightly different and more aggregate treatment was used for the services industries, as explained in more detail in Sections 2 and 3 of this Appendix. However, this by necessity still assumes that the share of domestically controlled firms in total exports of these industries is the same as observed for their share in goods. The emerging availability of STEC (Services Trade by Enterprise Characteristics) statistics will be able to mitigate this going forward. ${ }^{3}$ As before, an important assumption made here concerns consistency between TEC statistics and national IO tables. In reality, differences may exist because the statistical unit used in TEC is nearly always 'the enterprise,' whereas in many countries the unit for IO tables is 'the establishment' (see footnote 2). As was the case for AMNE, exhaustiveness adjustments for the nonobserved economy are not included in TEC. These are however not expected to form a significant source of difference as trade data is generally less affected by the non-observed economy (in most countries).

Step 3. Disaggregating 10 columns: Domestic intermediate use. Domestic purchases were calculated, by firm type, as the remainder of gross output less value added and less imports. This replicates the proportionality assumption introduced for imports, i.e., the domestically purchased product basket between domestically controlled firms and foreign-controlled affiliates is the same.

Step 4. Disaggregating 10 rows: Exports. The export column of national IO tables is split using exports by firm type (within industries) available from TEC with adjustments for exports by wholesalers/retailers (as explained in Box 1).

Step 5. Disaggregating 10 rows: Intermediate and domestic final demand. The final step in the transformation of the national IO table into splits by firm characteristics concerns the rows. From Step 4, the exports by firm type have already been calculated and so Step 5 allocates the remainder, output (from Step 1) less exports (from Step 4), to intermediate use and final consumption by firm type. This is perhaps the most important assumption used in creating the split IO table as, by design, it generates relationships between categories of firms (for example intermediate consumption of parts by foreign-controlled affiliates from domestically controlled firms). The approach used here takes a neutral position on these relationships by assuming that the share of residual output (output minus exports) for a given category of firm that is allocated to final demand (excluding exports) follows that seen for the industry as a whole. In practice this may generate a downward bias in the degree of upstream integration of domestically controlled firms as in many sectors these provide intermediate parts for foreign-controlled affiliates.

While this methodology introduces data by firm ownership with respect to their value added, output, imports and exports, a few important assumptions have been made. The first assumption is that 
there is no product heterogeneity in imports or domestic purchases. Within an industry, domestically controlled firms use the same products, and in the same proportions, as foreign-controlled affiliates. The second assumption is that there are no differences in preferences by users for purchasing from domestically controlled firms versus foreigncontrolled affiliates. Excluding exports, within an industry, both domestically controlled firms and foreign-controlled affiliates are assumed to provide products to (and purchase products from) other industries (intermediate use) and final consumers in the exact same proportion. These assumptions can be considered quite strong. Yet, they can be tested. Section 4 of this Appendix reports these tests and discusses the robustness of the findings obtained.

\section{Section 2: Data Imputations}

Given the degree of granularity that is required, countries often have to maintain confidentiality for some of the data points in AMNE and TEC statistics. Likewise, in view of the efforts involved to produce (in particular TEC) statistics, timeliness of the information is an issue for certain countries. However, a full set of information is required to disaggregate IO tables according to the methodology outlined above. Several steps and imputation methods were therefore used in the preparation of the data. First, only those countries with reasonable AMNE and TEC data coverage at the industry level were selected. ${ }^{4}$ However, the reported data still often contained missing values. These missing values were estimated, where possible, using either the aggregate growth rate (e.g., if data for domestically controlled firms in one industry were missing in one year but not in the next, they were estimated using the total growth of domestically controlled firms in that period), or by using the structure of previous years (e.g., if in one year a detailed breakdown was reported but not in the next, the shares from an earlier year were applied to the recent year totals). Data for those detailed ISIC Rev 4 industries that could be aggregated without affecting the ability to map them to the 34 industries were combined. ${ }^{5}$

Subsequently, the shares of both domestically controlled firms and foreign-controlled affiliates in total industry value added, gross outputs, imports, and exports were then calculated based on this data. While relatively straightforward for most industries, this involved several additional steps for business services, due to the fact that TEC data only cover merchandise trade and therefore are not a good approximation to develop a detailed breakdown of trade by firm ownership for individual services industries.

To address this issue, the imports and exports by firm ownership for 'Construction' (41T43), 'Transportation \& Storage' (49T53), 'Accommodation and Food Services' (55T56), 'Information Services and Communication' (58T63), 'Real Estate Activates' (68), 'Professional, Scientific and Technical Activities' (69T75), and 'Administrative and Support' (77T82) were combined to calculate a single value of the share of domestically controlled firms and foreign-controlled affiliates in the trade for these industries combined. By pooling the data, this estimate of the role of foreign-controlled affiliates in trade is less sensitive to idiosyncratic variations between services industries or over time.

Yet, as the information on the role of foreigncontrolled affiliates in the value added and output of individual services industries is available in AMNE, we combined this information with the broad estimate developed above. However, the results sometimes proved to be inconsistent. For example, the estimate of the role of domestically controlled firms in overall services exports could be $50 \%$, whereas the share of domestically controlled firms in output of one particular individual services industry could be as small as $10 \%$. Or vice versa, where the share of domestically controlled firms in output and value added is much higher. Therefore, the aggregate estimate of the share of domestically controlled firms in the exports and imports of services industries was then further adjusted for each individual service by aligning it more with the share of domestically controlled firms and foreign-controlled affiliates in output. The adjustment followed the intuitive reasoning that if the output of domestically controlled firms compared to foreign-controlled affiliates in one particular services industry is much larger than in services industry overall, it can be expected that its role in trade for that industry is also larger than the calculated average. In mathematic notion:

$$
X_{i}^{L}=\frac{O_{i}^{L} X_{S}^{L}}{O_{S}^{L}}
$$

where $X_{i}^{L}=$ the share of foreign-controlled affiliates in exports of individual services industry $i, O_{i}^{L}=$ the share of foreign-controlled affiliates in output of individual services industry $i$. 
A similar calculation was made for imports using output less value added instead of output. In addition to this imputation regarding the services industry, six other imputation methods were used to complete the dataset of shares of foreign-controlled affiliates (and as a consequence, domestically controlled firms) in value added, output, exports, and imports, in the following order: (1) simple linear interpolations; (2) using TEC export shares as a proxy for value added and gross outputs for the agriculture sector (01T03), as data in AMNE for the agriculture sector is missing in general; (3) mean imputation using country average share*industry average share/world average share for a specific variable; (4) correction applied if any imputed shares are greater than 1 , then set to the nearest acceptable time series value; (5) logic checks: if the share of domestically controlled firms and foreign-controlled affiliates in output is zero, then value added, imports and exports are also set to zero to avoid data conflicts; and (6) if the entire series is still missing, then foreign-controlled affiliates' shares in gross output was used to impute all other variables. To illustrate the extent to which we imputed data we prepared a table (available upon request) offering a detailed overview of the frequency of all imputations used for each country. Finally, to remove any idiosyncratic fluctuations in time series, 3-year moving averages were calculated for all series.

\section{Section 3: Data Inconsistencies Between Primary Statistics and National Accounts}

As noted above, primary statistics as available in TEC and AMNE are not fully consistent with comparable national accounts aggregates (nor always consistent with each other, as they are typically not collected by statistical offices in a single survey). As a consequence, an initial application of the methodology described above can introduce negative values which (with the exception of changes in inventories) should not occur. Three different types of negatives occurred, which were treated as follows. First, if a given firm-type's share in value added is high but its share in gross output is low, this may have the result that, when combined with IO data, gross output is less than value added. In turn, it suggests that the sum of domestic and imported intermediate inputs for the production is negative, which cannot be true. This happened mostly when a particular firm type was not very relevant in an industry - for instance, if domestically controlled firms were responsible for $4 \%$ of output but $8 \%$ of value added. In these cases, the distribution of value added is adjusted by lowering the share of the group where negatives occur up to the point where these disappear. To prevent this from happening in the first place, value added-tooutput ratios were constrained to not be more than 15 percentage points away from those in the original IO table.

Second, if a given firm-type's share in value added and in imports is relatively high as compared to its share in output, negative values may occur for domestic use of intermediates. In these cases, the distribution of imports is adjusted in a similar way as above for the firm type concerned, again making the other category absorb any differences. Finally, if a type of firms' share in gross output is relatively low compared to its share in exports, similar adjustments are made for the export shares. Among the various other options that were explored, this method ensured that the primary data were only minimally adjusted to ensure that IO data broken down by firm characteristics - in this case by firm ownership - continues to contain only positive figures.

\section{NOTES}

${ }^{1}$ Abbreviations used in this Appendix, in alphabetical order: $\mathrm{AMNE}=$ Activity of Multinational Enterprises (database); $\mathrm{CPC}=$ Central Product Classification; GVC = Global Value Chain; IO = Input Output; ISIC = International Standard Industrial Classification of all activities; OECD = Organization for Economic Cooperation and Development; SNA $=$ System of National Accounts; STEC $=$ Services Trade by Enterprise Characteristics (database); TEC $=$ Trade by Enterprise Characteristics (database); VAT = Value Added Tax.

${ }^{2} \mathrm{An}$ enterprise engaged in different activities has one or more locations. For the purposes of the System of National Accounts, it is divided accordingly into local units and engaged in homogeneous activities, called local kind-of-activity units. The combination of location and kind of activity of an enterprise results in what is called an establishment. Establishments allow for the possibility of carrying out one or more secondary activities, although they should be on a small scale compared to the principal activity. Therefore, establishments are a refined definition of enterprises which are in the same location and produce one kind of primary outputs. 
${ }^{3}$ Similar to TEC, STEC is designed to breakdown the service trade providers into groups with same business characteristics (e.g., by firm ownership). Since trade in services is a very complex definition compared to trade in goods, it is taking longer to develop this database. For more details on recent updates, see http://ec.europa.eu/eurostat/statisticsexplained/index.php/Services_trade_by_enterprise_ characteristics_-_STEC.

${ }^{4}$ Countries such as Australia, Canada, Greece, Ice land, Ireland, Israel, Japan, Korea, Luxembourg and Norway are eliminated from the analysis as excessive numbers of cells are suppressed for confidentiality reasons.

${ }^{5}$ For a variety of methodological reasons, certain parts of international trade may not be attributable to an individual firm. In TEC, these are classified as 'unknown.' When calculating the shares of domestic- and foreign-controlled firms in trade, the 'unknown' category is excluded from the calculation, as it may cause biases.

\section{ABOUT THE AUTHORS}

Fabienne Fortanier is Head of Department for Balance of Payments and Securities Statistics at the Dutch Central Bank. She previously worked as the Head of Trade Statistics at the OECD Statistics and Data Directorate, where the research presented in this paper was conducted. Dr. Fortanier holds a Ph.D. from the University of Amsterdam, Faculty of Economics and Business.

Guannan Miao has worked at the OECD since 2011. She is involved in the methodological development of Trade in Value Added, and has undertaken economic research and analysis for various OECD projects on Global Value Chains and on firm heterogeneity. She has published several working papers and newsletter articles on these subjects.

Ans Kolk is full professor at the University of Amsterdam, Amsterdam Business School, The Netherlands. Her areas of expertise are in corporate social responsibility, sustainable development, and sustainability, especially in IB and related GVCs. She has published numerous articles in international reputable journals, as well as book chapters and books. For more information and an overview of publications, see http://www.anskolk. eu.

Niccolò Pisani is Associate Professor of Strategy and International Business at the University of Amsterdam, Amsterdam Business School, The Netherlands. His areas of expertise are strategic management and international business. Among the topics of his scholarly enquiry are global strategy, international corporate social responsibility, and offshoring. His research has appeared in a variety of academic journals and practitioner-oriented outlets.

(c) (i) $\odot$ This work is licensed under a Creative Com NC No Commons Attribution-NonCommercial-NoDerivs 3.0 Unported License. The images or other third party material in this article are included in the article's Creative Commons license, unless indicated otherwise in the credit line; if the material is not included under the Creative Commons license, users will need to obtain permission from the license holder to reproduce the material. To view a copy of this license, visit http:// creativecommons. org/licenses/by-nc-nd/3.0/

Publisher's Note Springer Nature remains neutral with regard to jurisdictional claims in published maps and institutional affiliations.

Accepted by Klaus Meyer, Area Editor, 30 September 2019. This article has been with the authors for four revisions. 